NBER WORKING PAPER SERIES

\title{
WHY DO COMPANIES GO PUBLIC? AN EMPIRICAL ANALYSIS
}

\author{
Marco Pagano \\ Fabio Panetta \\ Luigi Zingales
}

Working Paper 5367

\author{
NATIONAL BUREAU OF ECONOMIC RESEARCH \\ 1050 Massachusetts Avenue \\ Cambridge, MA 02138 \\ November 1995
}

This paper is part of the research project on "The decision to go public and the stock market as a source of capital," promoted by the Ente "Luigi Einaudi" per gli studi monetari bancari e finanziari. The suggestions we received from Espen Eckbo, Tullio Jappelli, Mario Massari, Wayne Mikkelson, Marco Ratti, Jay Ritter, Andrei Shleifer, Jeremy Stein, and particularly Steve Kaplan were very helpful. We also benefitted from the comments of participants at the final conference of the research project in Rome, at the Nobel Symposium on Law and Finance, at the European Finance Association meetings in Milan and at a seminar at the Milan Stock Exchange Council. Fulvio Coltorti and Luca Filippa kindly supplied data and crucial information, and Stefania De Mitri and Paolo Filippo Volpin provided truly outstanding research assistance. Pagano also acknowledges financial support from the Consiglio Nazionale delle Ricerche, and Zingales from the Center for Research on Security Prices at the University of Chicago and NSF grant \#SBR-9423645. This paper is part of NBER's research program in Corporate Finance. Any opinions expressed are those of the authors and not those of the National Bureau of Economic Research.

(C) 1995 by Marco Pagano, Fabio Panetta and Luigi Zingales. All rights reserved. Short sections of text, not to exceed two paragraphs, may be quoted without explicit permission provided that full credit, including $\mathbb{C}$ notice, is given to the source. 


\title{
WHY DO COMPANIES GO PUBLIC? \\ AN EMPIRICAL ANALYSIS
}

\begin{abstract}
This paper empirically analyzes the determinants of an initial public offering (IPO) and the consequences of this decision on a company's investment and financial policy. We compare both the ex ante and the ex post characteristics of IPOs with those of a large sample of privately held companies of similar size. We find that (i) the likelihood of an IPO is positively related to the market-to-book ratio prevailing in the relevant industrial sector and to a company's size, (ii) IPOs are followed by an abnormal reduction in profitability, (iii) the new equity capital raised upon listing is not used to finance subsequent investment and growth, but to reduce leverage, (iv) going public reduces the cost of bank credit; $(v)$ it is often associated by equity sales by controlling shareholders, and is followed by a higher turnover of control than for other companies.
\end{abstract}

Marco Pagano

Universitá di Napoli

Via Catullo, 64

80122 Napoli

ITALY
Fabio Panetta

Banca d'Italia

Via Nazionale, 91

00184 Roma

ITALY
Luigi Zingales

Graduate School of Business

University of Chicago

1101 East 58th Street

Chicago, IL 60657

and NBER 
The decision to go public is one of the most important and least studied questions in corporate finance. Most corporate finance textbooks (e.g., Brealey and Myers, 1991) limit themselves to describing the institutional aspects of this decision, providing only a few remarks on its ultimate motivation. The conventional wisdom is that going public is simply a stage in the growth process of a company. Although there is some truth in it, this "theory" alone cannot explain the observed pattern of listings. Even in well developed capital markets, like the U.S., some large companies - such as United Parcel Service or Bechtel - are not public. ${ }^{1}$ In other financial systems, like Germany and Italy, publicly traded companies are the exceptions rather than the rule, and quite a few private companies are many times larger than the average publicly traded company. These cross-sectional and cross-country differences indicate that going public is not a stage that all companies eventually reach, but it is a choice. This begs the question of why some companies choose to use public equity markets and some don't. Beside its obvious intrinsic interest, an answer to this question can increase our understanding of the functions performed by the stock exchange as a source of capital.

This paper empirically analyzes the determinants of an initial public offering (IPO) and the consequences of this decision on a company's investment and financial policy. The determinants of the decision to go public can be inferred both from the ex ante characteristics of the companies which go public and from the ex post behavior and performance of these companies after the date of flotation. In principle, if the relevant decision makers have rational expectations, the two methods should give consistent answers: the motives to go public uncovered on the basis of "ex ante evidence" should square with the "actual effects" of flotation. But in practice, rather than being redundant, ex post information is likely to complement the evidence based on the ex ante characteristics of the companies which go public, for two reasons. First, the importance of some variables can be assessed only by looking at ex post data: for example, the controlling shareholders' intention to divest after flotation can hardly be gauged from ex ante information. Second, in some cases the effects of the flotation may not be fully anticipated, so that only ex

\footnotetext{
${ }^{1}$ Just to give a sense, in 1992 UPS had $\$ 16.5$ billion in sales and 267,000 employees. Bechtel group had $\$ 7.8$ billion in sales and 31,000 employees.
} 
post information can uncover them. Thus, we attack the issue of "why companies go public" by using both ex ante and ex post information on their characteristics and performance.

One of the difficulties of such a study is that we generally do not have information for the companies that did not go public. To overcome this problem we use a data set of Italian companies that contains financial information for a large sample of both publicly traded and privately held firms. This data set is unique in several respects. In the first place, we effectively observe a large proportion of the companies that can go public, rather than a sample of those that did go public. This implies that (i) we have data on a very large control group of privately held companies which do not go public within the sample period and (ii) we observe companies which eventually go public many years before this choice. Thus our data do not suffer from the sample selection bias that would be present if they had been collected only for the companies which actually went public.

Our data are also very interesting because they include information on company accounts and on the actual bank rates. This allows us to evaluate whether the terms at which companies borrow from banks affect their decision to go public and, conversely, if the decision to go public affects the terms subsequently offered by banks. The availability of this data is important, considering that in most countries banks are the main source of external finance to companies.

The cost of using such a dataset is that some of the conclusions of this study are not easily comparable with the U.S. evidence on the subject and cannot be necessarily generalized to the U.S.. As we explain, Italy has an underdeveloped and undercapitalized stock market. Nevertheless, Italy is not unique in this dimension: most Continental European countries are similar. Therefore, it is reasonable to expect that most of our findings extend to these countries as well. Evidence in this direction is provided by Planell (1995), who replicates our study with Spanish data and finds quite similar results. Therefore, by studying what leads a company to use (or not to use) the public equity market, we hope to provide the groundwork for future investigations of the economic role played by stock markets in Continental Europe.

We find that the main factor affecting the probability of an IPO is the market-to-book ratio at which firms in the same industry trade: a one-standard deviation increase in the market-to- 
book ratio raises the odds of an IPO by $25 \%$. This positive relationship may reflect a higher investment need in sectors with high growth opportunities (and correspondingly high marketto-book ratios) or the entrepreneurs' attempt to time the market. Our finding that investment decreases after the IPO points to the latter explanation.

The second most important determinant is the size of a company: larger companies are more likely to go public. It is also true that IPOs tend to be companies that grow faster and are more profitable. These results are true even if we control for the fact that IPOs must satisfy certain profitability conditions in order to list on a stock exchange.

We also identify a significant difference between the factors underlying the decision to go public taken by an independent company and taken by the subsidiary of a publicly traded company (carve-out). Independent companies are more likely to go public after major investments and abnormal growth. The IPO is followed by a reduction in leverage and investment. So their decision to go public can be interpreted as an attempt to rebalance their balance sheet after large investments and growth. By contrast, the main force behind carve-outs appears to be the desire to maximize the proceeds from selling shares in a subsidiary, since these IPOs are particularly sensitive to a "window of opportunity".

Among the post-IPO effects we find a reduction in profitability - a phenomenon consistent with the findings by various authors in the U.S. (Degeorge and Zeckhauser, 1993; Jain and Kini, 1994, and Mikkelson, Partch, and Shah, 1995). This effect survives, albeit the magnitude is smaller, even if we control for the fact that companies must satisfy certain profitability conditions in order to list on Italian stock exchanges. We also find a reduction in investment and financial leverage. All these effects do not appear to be limited to the initial three years after the IPO, but they persist longer, though to a smaller extent.

We also document - as far as we know for the first time - that independent IPO firms experience a reduction in the cost of their bank credit. This effect is present even when controlling for firms' characteristics and for the reduction in leverage experienced after going public. Moreover, after the IPO these firms borrow from a larger number of banks and reduce the concentration of their borrowing. At this stage we are unable to distinguish whether rates drop because access to 
the stock exchange improves the public information about a company or because this information and the availability of an outside source of funds increases a firm's bargaining position vis-à-vis its banks.

We find little evidence that portfolio diversification plays an important role in the decision to go public. When an independent company undertakes an IPO the initial owners divest only 6 percent of their holdings at that date and 3 percent more in the subsequent three years, retaining much more than a majority stake. Divestments are much larger (18 percent) for carve outs, and the amount divested is negatively correlated with the ex-post accounting performance, as predicted by Leland and Pyle (1977) and Jensen and Meckling (1976). Finally, we find that in the three years following an IPO there is a larger than normal increase in turnover of the controlling group, emphasizing the importance of looking at an IPO as a stage in the process of selling a company, as suggested by Zingales (1995a).

The paper is organized as follows. Section 1 surveys the main hypotheses about why companies go public, stressing their respective testable implications, and also the results of relevant empirical work. Section 2 provides a description of the institutional and regulatory environment in which Italian companies operate, as well as some historical data on IPOs in Italy, to help put our empirical results in perspective. In section 3 we describe the data - a panel of 2,181 companies for the years 1982-92. Section 4 analyzes the determinants of the decision to go public on the basis of the companies' ex ante characteristics and behavior. Section 5 reports the effects of an IPO on profitability, investment, financial policies and the cost of credit. Finally, section 6 studies the changes in ownership and control following an IPO, and relates them to post-IPO profitability. Section 7 concludes the paper.

\section{Competing Theories}

This section provides a general overview of the existing theories on the decision to go public that guides our empirical work. The decision to go public is so complex that no single model can hope to capture all of the relevant costs and benefits. But almost all of the effects of this decision 
have been evaluated in one model or another. Although these theories can hardly be nested in a single model, one can derive a set of (not mutually exclusive) testable predictions from them. In Table 1 and in the rest of this section we summarize the predictions of the main models.

\subsection{The costs of going public}

\subsubsection{Adverse selection and moral hazard}

The adverse selection cost of IPOs is the most actively researched aspect of the problem. When investors have imperfect information, it is low-quality companies which have the greatest incentive to go public, which affects adversely the IPO price - as highlighted by Rock (1986) and many others later on. This argument has been advanced to explain the fact that the prices of initial offerings are below the closing price in the first trading days in the secondary market, i.e. the "IPO underpricing" documented by many authors (see the survey in Loughran, Ritter and Rydquist, 1994).

The adverse selection cost is a more serious obstacle to the listing of young and small companies, which have little track record and visibility, than for old and large companies. So in the presence of adverse selection, the probability of going public should be negatively correlated with the age or the size of the company. This prediction emerges from the model by Chemmanur and Fulghieri (1994). They highlight that the public issue of equity to many shareholders has large costs in terms of information collection, due to the duplication of the investors' effort, but entails efficient risk-sharing; in contrast, private financing by a single venture capitalist minimizes information production costs but implies inefficient risk sharing and therefore a larger risk premium. So private finance from a venture capitalist is efficient for young, little-known companies, while the public issue of equity is more suited to older, better-known companies. The same result obtains in agency models, where the controlling shareholder has an incentive to extract private benefits at the expense of external investors. Diamond (1991) predicts that in the presence of moral hazard young companies borrow from banks, who can limit opportunistic behavior via monitoring, while older companies with a good public track record issue debt in public markets. 
A second common prediction of adverse selection and moral hazard models is a positive relationship between the share retained by the controlling shareholder and the profitability of the company after the IPO. As shown by Leland and Pyle (1977), if the initial owners have private information about the company, their divestment can be interpreted by the market as a symptom that the company is unprofitable. As a result, to signal the profitability of their company its owners must retain a stake so large as to incur a cost in terms of forgone diversification. Similarly, the classic paper by Jensen and Meckling (1976) predicts that as the stake of the controlling shareholder is reduced, the incentives for him to extract private benefits will increase, and therefore lower the company's value to external shareholders.

\subsubsection{Administrative expenses}

Beside the initial underpricing, going public implies considerable direct costs: underwriting fees, registration fees, etc. On top of the initial expenses, one must consider the yearly layouts on auditing, certification and dissemination of accounting information, stock exchange fees, etc. Many of these expenses do not increase proportionally with the size of the IPO, and therefore weigh relatively more on small companies: Ritter (1987) has estimated that in the U.S. the fixed costs equal approximately $\$ 250,000$ and the variable costs are about 7 percent of the gross proceeds of the IPO.

\subsubsection{Loss of confidentiality}

The disclosure rules of stock exchanges force companies to unveil information whose secrecy may be crucial for their competitive advantage, such as data about ongoing R\&D projects or future marketing strategies. They also expose them to close scrutiny from tax authorities, reducing their scope for tax elusion and evasion relative to private companies. Campbell (1979) was first to point to confidentiality as a deterrent from getting funding in public markets. Yosha (1995) has shown that in equilibrium firms with more sensitive $R \& D$ information are deterred from going public if the costs of a public offering are sufficiently high. In a related paper, Bhattacharya and Chiesa (1994) show that, in the context of an R\&D race, incentive problems may force companies 
into bilateral, exclusive relationship with a lender, in order to avoid information spillovers to competitors. So, if the loss of confidentiality is a relevant concern, high tech companies should be less likely to go public.

\subsection{The benefits of going public}

\subsubsection{Overcoming borrowing constraints}

A key benefit of going public is to gain access to a source of finance alternative to banks. In the presence of informational asymmetries, a company with large external funding needs may face high interest rates or even credit rationing. Issuing external equity can relieve this financing constraint. On this account, one should expect companies with large investment outlays and high leverage to be more likely to go public, and newly listed companies to increase their investment or reduce their debt exposure after the IPO. Another testable implication of financial constraints is that newly listed companies should not increase their payout ratio after the IPO.

\subsubsection{Greater bargaining power with banks}

Another potential problem with bank loans is that banks can extract rents from their privileged information about the credit worthiness of their customers. By gaining access to the stock market and disseminating information to the generality of investors, a company elicits outside competition to its lender and ensures a lower cost of capital, a larger supply of external finance or both, as highlighted by Rajan (1992). The prediction here is that the companies which pay higher interest rates are more likely to go public, and that the cost of credit falls and the availability of credit lines increases after an IPO, after controlling for profitability and leverage.

\subsubsection{Portfolio diversification}

The decision to go public increases the scope for diversification by the initial holders of the company, whose portfolios are generally loaded with equity in the "family company" when this is private. This diversification can be achieved directly, by divesting from the company and 
reinvesting in other assets, or indirectly, by having the company raise fresh equity capital after the IPO and acquire stakes in other companies. If diversification is an important motive in the decision to go public, as in Pagano (1993), the riskier companies are more likely to go public, and one should observe the controlling shareholders selling a substantial portion of their shares at the time of the IPO or soon afterwards.

\subsubsection{Stock market discipline}

Going public can decrease the agency problems between shareholders and managers, because the stock market provides additional ways to discipline management. One source of market discipline is the danger of a takeover by raiders who can run the company better than incumbent managers (an argument which requires the potential raider to have a sufficiently large initial stake in the company, as shown by Shleifer and Vishny, 1986). In addition, Holmström and Tirole (1993) point out that the shareholders of a public company can use the information reflected in stock prices to design more efficient compensation schemes for their managers, for instance by indexing their salaries to the stock price or by offering them stock options. Unfortunately, we cannot test this hypothesis because Italian companies do not disclose data on the structure of managerial compensation.

\subsubsection{Liquidity}

The shares of private companies can be traded only by informal searching for a counterpart, at considerable cost for the initiating party. In contrast, the shares of public companies can be traded on an organized exchange, which is cheaper for small shareholders who want to trade on short notice. Providing liquidity services to shareholders in a more cost-effective way translates into a higher price for the company's shares. Thus, if the initial owners of the company want to sell to dispersed shareholders they have an inducement to go public. If instead the company stays private, to minimize liquidity costs they must sell stakes only to a few large shareholders, 
who will generally demand a monitoring role in the company. ${ }^{2}$ Pagano and Röell (1995) show that, as a result, the initial owners may have to accept over-monitoring if they stay private. If the scale of the planned expansion is very large, the cost of this over-monitoring becomes so large that it is preferable to go public. So this model also predicts a positive correlation between the probability of an IPO and the scale of the subsequent investment.

\subsubsection{Investor recognition}

It is well known that most investors hold portfolios which contain only a small fraction of the existing securities, often because they simply ignore that a certain company exists. Listing on a major exchange can help to overcome this problem, by acting as an advertisement for the company. Merton (1987) has captured this point in a capital asset pricing model with incomplete information, showing that stock prices are higher the greater the number of investors aware of the company's securities. This is consistent with the fact that when companies already listed elsewhere announce their decision to list also in New York, their stock yields a 5 percent abnormal return on average (Kadlec and McConnell, 1994).

\subsubsection{Change of control}

Zingales (1995a) points out that going public can also be viewed as an optimal first step in the process of selling a company. In this context, he argues that selling off a minority stake to dispersed shareholders may increase the amount of surplus the initial owner can extract from a future buyer of the majority stake, increasing the total proceeds the initial owner can fetch selling the company. If this is an important motivation behind the IPO we expect a high incidence of control transfers after the IPO. As Bebchuk and Zingales (1995) suggest, though, this benefit may induce a socially excessive incidence of public companies controlled by large shareholders.

\footnotetext{
${ }^{2}$ Bolton and von Thadden (1995) analyze the design of the corporate ownership structure, highlighting that a dispersed shareholder base is an efficient way of producing liquidity but provides less shareholders' monitoring of managers compared with a concentrated shareholder base.
} 


\subsubsection{Windows of opportunity}

If there are periods in which stocks are mispriced, as suggested by DeLong et al. (1990), companies which realize that other companies in their industry are overvalued have an incentive to go public. This "window of opportunity" hypothesis, modelled and tested by Rajan and Servaes (1995), is consistent with international time-series evidence in the 1980s (Loughran, Ritter and Rydqvist, 1994). It is also consistent with the cross-sectional clustering of IPOs near sectorial stock price peaks (Ritter, 1984) and Lerner (1994). It is also consistent with low long-run returns (Ritter, 1991, Loughran and Ritter, 1995).

\subsection{Existing empirical work}

While we are not aware of any comprehensive study trying to compare the various determinants of the decision to go public, there are many studies directly or indirectly shedding light on some of them. Most of the existing empirical work in this area concentrates on the top and bottom right corner of Table 1: the IPO underpricing and the long term underperformance of the stocks of new public companies. Few studies focus instead on the characteristics of the companies which go public, the motives of their decision and the subsequent performance of these companies.

The only two such studies for U.S. data are by Jain and Kini (1994) and Mikkelson, Partch, and Shah (1995), while in the context of leveraged buyouts the return to public ownership has also been studied by Kaplan (1991) and Degeorge and Zeckhauser (1993). Jain and Kini document that, after an IPO, firms experience a significant decline in operating performance, but that this decline is smaller for firms where the original entrepreneurs retain more equity, in agreement with the prediction of Leland and Pyle (1977). Mikkelson, Partch, and Shah also report that the operating performance of the companies declines to a below-average level after an IPO (down from an above-average level in the year before the IPO), even though their growth remains relatively strong. But, in contrast with Jain and Kini, Mikkelson, Partch, and Shah find that the companies with lowest post-IPO profitability are those where existing holders and managers retain the largest stake, although this difference is not statistically significant. 
The dismal post-IPO profitability is consistent with the claims that IPOs time the market and with the post IPO stock price underperformance. Lerner (1994) finds that biotechnology companies go public near the peak of biotech equity valuations, and in targeting these peaks they receive considerable help by venture capitalists. Ritter (1991) and Loughran and Ritter (1995) documents a strong underperformance of IPO companies respectively in the three and five years following the offering.

Mayer and Alexander (1991) use another approach to analyze the British evidence: rather than analyzing companies around their IPO date, they compare the characteristics and performance of 544 British public companies with those of 56 large companies that stay private from 1980 to 1987. Controlling for size and sector, they find that public companies invest more, grow more rapidly, are more profitable and pay out more dividends than private companies. They also raise more equity finance, but use it to purchase stakes in other companies rather than for direct investment. Finally, public companies are concentrated in sectors with comparatively advanced technology (contrary to what Campbell (1979) and Yosha (1995) predict).

Rydqvist and Högholm (1994) study the change in ownership, leverage and size in 164 familyowned firms that went public in Sweden in the period 1970-1991. According to their results, IPOs in Sweden are more likely to be done by older firms, often by owners who want to divest, consistent with the predictions of Zingales (1995a). In 59 companies the initial owners sold out all their shares within 5 years from the IPO, and on average they reduced their net holdings in the company by half. Correspondingly, most companies have not used the IPO as an opportunity to reduce leverage or finance company growth. These findings appear to contradict the selfreported reasons offered by the initial owners of these companies in the IPO prospectuses: in 97 percent of the cases in which a motivation was stated, the IPO was presented as aiming at firm financing, whereas only 14 percent of the prospectuses stated the aim of rebalancing the portfolio of the initial owners. Instead, 38 percent of the prospectuses mention incentives to employees (in Sweden the distribution of shares to employees is favored by the tax code) and 67 percent mention publicity as a motivation to go public.

Also in Italy, the need to finance investment and growth is the most commonly quoted motive 
to go public in self-reported information. Ferrari (1992) reports the replies of the controlling shareholders to a questionnaire distributed in the context of 35 IPOs between 1985 and 1990. In 95 percent of the cases, new financing was mentioned as an important reason to go public. ${ }^{3}$ Other alleged reasons were the improvement in corporate image (57 percent), the increase in the liquidity of the stock ( 43 percent) and the need to mark the move from a family business to a large company (23 percent). As we shall see below, our evidence shows that new public companies did raise new equity capital after the IPO (as found also by Gualtieri (1988) on a much smaller sample), but this was not mainly directed to finance investment and growth.

Another questionnaire proposed by Basile (1988) in Italy investigates the impact of the decision to go public on the relationship with banks. Even though only 18 companies responded, it is worth mentioning that 10 of the respondents stated that upon going public the company had improved their standing with banks by obtaining cheaper credit, lower collateral requirements and better service. When asked to state the motives of this improved treatment by banks, 6 pointed to the greater transparency of accounting information and 4 to the greater flexibility in their financing choices. Moreover, the 8 respondents who said that their companies were not treated any better by banks attributed this to the strong bargaining power that their company (or its holding company) already enjoyed with banks. These results are supported by our evidence on a much larger sample.

Finally, Rondi et al. (1994) report descriptive evidence on the differential behavior of listed and unlisted companies in Italy that stands in partial contrast with the findings by Mayer and Alexander for Britain. Italian listed companies appear to be less profitable and to have lower fixed investment than unlisted ones, but are less leveraged, more capital intensive and pay more dividends.

\footnotetext{
${ }^{3}$ Also the owners of companies that choose to stay private explain their preference as due to the fact they have no need of external finance. For instance Mr. Barilla, owner of the 9th largest group in the country, has recently declared: "We have no plan to list our company in the near future. One of the reasons is that we have the \$200-220 million in cash-flow to cover any possible investment need we might have." Il Mondo, 8 November 1993.
} 


\section{The Institutional Environment}

As will be clear momentarily, our sample allows us to investigate the determinants of the decision to go public for Italian firms in the 1982-1992 period. To place our study in perspective, this section provides a brief historical overview of the characteristics of the Italian stock market in general, and of this period in particular.

The Italian stock market is rather small in comparison with the scale of the underlying economy: in 1987 (the mid-year of our sample) its total capitalization was 16 percent of Italy's GDP, compared to 49 percent for the USA, 99 percent for Japan and 42 percent for the U.K. ${ }^{4}$ The relatively small scale of public equity markets, however, is typical in Europe: in 1987, all the national stock markets in the European continent had a capitalization of 20 percent or less of GDP, with the exceptions of Switzerland, Sweden and the Netherlands. In Italy, Germany and France, this reflected the small number of companies listed on the stock exchange rather than their average size: the average capitalization of the companies listed in Milan, Paris and in the German exchanges was respectively $1.9,1.15$ and 1.4 times as large as that of the companies listed at the New York stock exchange (see table 1 in Pagano, 1993).

The paucity of publicly traded companies cannot be attributed to a lack of companies that could go public. As Massari (1992) clearly establishes, in the 1987-89 period, at least 1,163 Italian private companies satisfied the listing requirements and could have gone public. Even excluding subsidiaries of foreign companies or of domestic public companies, there were 851 possible candidates. While 413 of these companies were small (with an estimated market value less than 25 billion Lire, compared to the average public company market value of 803 billion Lire), 76 of them had an estimated market value above 100 billion Lire (roughly US\$70).

A second distinguishing feature of the Italian stock market is the high concentration of ownership in publicly traded companies. As Zingales (1994) reports, the majority of companies listed

\footnotetext{
${ }^{4}$ In the following we will identify the Italian Stock Exchange with the Milan Stock Exchange, which is by far the most important and liquid stock exchange in Italy. For the sample period considered this identification is without loss of generality. Only at the beginning of the century does the issue of "most important" market become more controversial.
} 
on the Milan Stock Exchange have a large shareholder who owns more than $50 \%$ of the voting rights. In Italy, virtually all companies are controlled by a large shareholder. Nevertheless, this situation is not unique. For example, Franks and Mayer (1994) find a very high concentration of ownership among German companies. So when an entrepreneur decides to take his company public in Italy, he is likely to retain majority control.

As Figure 1 shows, the scarcity of public companies is nothing new in Italy. The total number of public companies has been surprisingly stable since the turn of the century: it has fluctuated around an average of 144 companies, hitting a minimum of 108 companies in 1917 and a maximum of 228 in 1992, with a trend increase of a mere 0.2 percent per annum. The number of public companies has increased substantially only in three periods: during the first spurt of Italian industrialization (1897-1907), in the period after WW1 (1923-1930) and finally in the second half of the 1980s. In this respect our sample period is interesting because it captures not only one of the few IPOs waves in Italy, but also some years afterwards.

Figure 1 suggests that a stock market boom is a necessary but not sufficient condition for an IPO wave. ${ }^{5}$ When the number of public companies has been most variable - before 1935 and after 1985 - it is strongly correlated with real stock prices, while this is not true of the intermediate period: the long stock price rally that lasted from the late 1940 s to 1960 stimulated virtually no IPOs. ${ }^{6}$

The most surprising feature is the lack of IPOs in the post WW2 era. While in the preWW2 era the fluctuations in the number of listed companies follow closely the fluctuations in stock prices and in the level of economic activity, this relationship is absent after the war. The two decades following WW2 were characterized by the extraordinary growth of the Italian manufacturing sector (the Italian miracle) and rising stock market prices. Despite these two

\footnotetext{
${ }^{5}$ Figure 1 reports the number of companies listed; this is affected both by entries (IPOs) and exits (delisting). However, except for 1918 and for the early 1930s delistings are very limited and not highly variable, and so the reader can easily infer the number of IPOs from the changes in the number of companies listed.

${ }^{6}$ This visual impression is confirmed by regression analysis: regressing the change in the number of public companies on the current and two lagged values of real stock price changes for the period 1905-93 (excluding the years of WW1), one finds that current and lagged stock price changes are jointly significantly different from zero at the 1 percent confidence level if the whole 1905-1993 sample is used, but are not significant at conventional confidence levels if the sample is restricted to the 50 year interval between 1935 and 1985.
} 
factors, it is not until 1985 that we have another substantial flow of IPOs.

This feature is not peculiar only to Italy: Rydqvist and Högholm (1994) report that Austria, Finland, Germany, Sweden and Switzerland had very few IPOs in the 1960s, despite high levels of real stock prices in that decade. In contrast, the stock market boom of the mid 1980s has been associated with a wave of IPOs virtually everywhere.

All this suggests that the "window of opportunity hypothesis" is not an exhaustive explanation of the decision to go public. The aim of this paper is to use the evidence from individual company data to answer the questions raised by the puzzling time-series evidence.

\section{Data}

\subsection{Sources}

We have three main sources of data. Balance sheet and income statement information come from the Centrale dei Bilanci database (Company Accounts Data Service). Information about interest rates, loan sizes and lines of credit are drawn from the Centrale dei Rischi database (Central Credit Register). Information about ownership and control are drawn from IPO prospectuses and from the Taccuino dell'azionista (Stock Exchange Companies Handbook). In some occasions (see below), additional balance sheet data have been collected directly from companies' annual reports. Since the first two data sources are quite novel, we provide some information on their content below. ${ }^{7}$

The Centrale dei Bilanci provides standardized data on the balance sheets and income statements of about 30,000 Italian non-financial firms. The data has been collected since 1982 by a consortium of banks interested in pooling information about their clients. A firm is included in the sample if it borrows from at least one of the banks in the consortium. The database is highly representative of the Italian non-financial sector: a recent report (Centrale dei Bilanci, 1992), based on a sample of 12,528 companies drawn from the database (including only the companies

\footnotetext{
${ }^{7}$ The only published study to merge data from the Centrale dei Bilanci with information on interest rates and loans obtained from the Centrale dei Rischi that we are aware of is Faini, Galli and Giannini (1993).
} 
continuously present in 1982-90 and with sales in excess of 1 billion Lire in 1990), states that this sample covers 57 percent of the sales reported in national accounting data.

The Centrale dei Rischi is a department of the Bank of Italy in charge of collecting data on individual loans over 80 million Lire granted by Italian banks to companies and individuals. ${ }^{8}$ These data are filed compulsorily by banks and are made available upon request to individual banks to monitor the total exposure of their customers. In addition, 79 banks (accounting for over $70 \%$ of total bank lending) have agreed to file detailed information about the interest rates charged on each loan. These data, which are collected for monitoring purposes, are highly confidential: no one except a few select officials at the Central Bank of Italy can access them.

The third source of our data is the IPO prospectuses prepared for companies that undertook a public offering before being listed. The prospectuses are the only source that allows us to reconstruct the ownership structure of these companies before they went public. They are available for 62 of the 69 non-financial companies listed on the MSE between 1982 and 1992 and present in our panel data set. ${ }^{9}$ Finally, information about ownership structure and control after these companies went public can be found from published sources (Taccuino dell'azionista). ${ }^{10}$

\subsection{Sample}

The sample is drawn from the Centrale dei Bilanci. Since our purpose is to study the determinants of the decision to go public, we want to restrict our attention to companies that have at least a minimal probability of going public during the 11 years of our sample.

A 1975 law made CONSOB (the Italian analog of the SEC) responsible for establishing the minimum listing requirements for any Italian Stock Exchange. However, it was only in 1984 that

\footnotetext{
${ }^{8}$ The limit drops to 10 million Lire after a firm's insolvency.

${ }^{9}$ The remaining 7 companies did not file a prospectus at the MSE for a variety of reasons: 4 were already listed on the Mercato Ristretto (Industrie Secco, Auschem) or on minor stock exchanges (Tripcovich, Fisia); 1 company was exempted because its privileged shares were already listed on the MSE (SAES Getters); 1 went public by merging with an already listed company and restructuring it completely (Parmalat); 1 became listed in New York (Luxottica).

${ }^{10}$ We have the ex post data for all the companies in our panel except one (Luxottica), 38 financial companies plus 6 industrial companies not present in the panel dataset.
} 
the CONSOB explicitly specified two requirements for listing:

(i) book value of shareholders' equity in excess of 10 billion Lire;

(ii) positive earnings in the last 3 years before listing. Both these criteria, though, could be waived with the CONSOB's agreement, at least until 1989. In that year the CONSOB strengthened its requirements, by mandating that profitability measures be obtained independent of intra-group operations and extraordinary items. The new directive also dropped any mention about the possibility of waiving the shareholders' equity criterion, while the profitability criterion could be waived only in the presence of major and permanent changes in a company's structure. ${ }^{11}$

The changing regulatory environment and its flexibility induced us to use a very mild criterion to extract our basic sample. We included all the companies that as of 1982 had at least Lire 5 billion in shareholder's equity. This criterion reduces the Centrale dei Bilanci sample to 2,181 companies. The sample contains $89 \%$ of non-financial companies which went public during the sample period. We apply this first screening to eliminate a large number of small and very small businesses whose accounting data are typically quite unreliable. ${ }^{12}$ The cost is that we lose two companies that went public during the sample period, but did not reach 5 billion in shareholders' equity in 1982. In the empirical analysis, though, we will from time to time impose more restrictive requirements to see the robustness of our results to the selection bias produced by the fact that new public companies have to meet certain listing requirements.

As Barca et al. (1994) have shown, Italian industry is generally organized around multicompany groups controlled by a single family via a holding company. This poses problems in establishing when a company can be considered as publicly traded. In fact, when a group holding company is listed, all its subsidiaries might get some of the benefits and/or bear some of the costs of being public: for instance they can indirectly access the public equity market to finance investments, but they must bear the cost of certified auditing as part of the parent company's

\footnotetext{
${ }^{11}$ However, in such cases at least the last income statement should show some positive earnings.

${ }^{12}$ We also considered an alternative criterion based on total assets. We preferred one based on shareholders equity for two reasons. First, it is directly linked to one of the listing requirements. Second, it eliminates many big government-owned firms with negative shareholders' equity (for example ENEL, the Government-owned monopoly producer of electric power).
} 
disclosure requirements. This does not preclude these companies from seeking to be separately listed (in such case we would have a spin-off or a carve-out).

The reasons why these companies go public and the consequences of this decision may be different from those of an independent company or of a subsidiary of a private holding company. Therefore, we create a separate category to account for subsidiaries of publicly listed companies. Similarly, we will distinguish between new listing of independent companies and new listing of subsidiaries of publicly traded companies (which we shall collectively name carve-outs). ${ }^{13}$

Another problem created by this group structure is that all the listed holding companies are, by definition, financial companies. In many cases this classification is misleading because it ignores the fact that some holding companies concentrate the vast majority of their assets in a single industrial company. For example, the Benetton family controls its industrial and commercial activities through Benetton Group SPA, a financial holding company listed on the Milan Stock Exchange since 1986, but $95 \%$ of the consolidated sales of group are due to Benetton SPA, a textile subsidiary. Even though Benetton SPA de facto coincides with Benetton Group SPA, formally it is not a listed company. We overcome this problem by classifying Benetton Group as a textile company. In addition, since our data set provides accounting information only for industrial companies, we replace the missing data from the consolidated accounts of Benetton Group with the accounting data of its textile subsidiary. We follow this procedure only if a listed holding company owes more than $75 \%$ of its consolidated sales to a single subsidiary. This happens in 6 cases. ${ }^{14}$

The final problem in identifying when a firm "goes public" is in establishing the proper definition of when a company can be considered publicly traded. Besides the Milan Stock Exchange (MSE), by far the most important one, there are in Italy 9 other minor stock exchanges located in different Italian cities, plus some more informal markets, called "Mercati Ristretti". The minor stock exchanges, however, have very little volume. and there is only one informal market of any

\footnotetext{
${ }^{13}$ All new listings of subsidiaries of publicly traded companies except one are technically carve-outs. One case (Comau) is a spin-off.

${ }^{14}$ These companies are: Benetton Group, Boero Bartolomeo, Pininfarina, Raggio di Sole Finanziaria, SISA, Tripcovich.
} 
size, which is in Milan. Even this market, though, is not very liquid and until February 1987 prices were recorded only once a week.

We choose as our main definition of IPOs all the new listings to the Milan Stock Exchange. Alternatively, we could have defined the date of new listing as the earliest date at which a company started to be listed in any of the above markets. ${ }^{15}$ As Table 2 shows the two definitions do not differ widely and all the results are substantially unchanged. Therefore, we report only the results using the first definition.

There were 139 new listings on the MSE during the period 1982-1992. Of these new listings 25 were banks and insurance companies, which we excluded from the sample because of intrinsic differences in the nature of their operations and accounting information. Of the remaining ones, 44 are classified as financial companies by Indici e Dati, a stock handbook. As previously mentioned, 6 of these so-called financial companies were so closely identified with one industrial subsidiary, that we simply used the industrial subsidiary for all accounting information.

This leaves a total of 76 new listings. Of these, we lose 3 observations because the company was incorporated after 1982 and another observation because the company did not satisfy the requirement of Lire 5 billion in shareholders' equity in 1982. Finally, we lose 5 companies because they were not reported in the Centrale dei Bilanci as of 1982 . To these we add a company which went public in a nonstandard way (Parmalat) and one which listed in New York instead of Milan (Luxottica). ${ }^{16}$ So the final sample contains 69 companies. 40 of these are new listings of independent companies, while 29 are carve outs.

Table 2 presents the distribution over time of new listings in our sample using the first and second definition. It is quite clear that new listings are highly concentrated in the period 1986 and 1987. This clustering of IPOs is a well established phenomenon both in the U.S. (Ritter, 1984) and other countries (Loughran, Ritter and Rydqvist, 1993, and Ljungqvist, 1995). Note

\footnotetext{
${ }^{15}$ During our sample period we are aware of only one company that started to be listed in a foreign market before being listed in Italy. This is Luxottica, which listed on the NYSE in 1990.

${ }^{16}$ In 1990 Parmalat merged into a listed financial company (Finanziaria Centro Nord) and reorganized it completely under the name of Parmalat. We take this to be effectively equivalent to a new listing. Luxottica went public on the New York Stock Exchange in 1990. We assume that the effects of this choice are comparable to those of listing on the MSE.
} 
that, unlike most stock exchanges, the MSE peaked in May 1986. Therefore, the IPO "hot market" followed the stock market boom with a small time lag.

\subsection{Summary Statistics}

Table 3 contains some summary statistics on our entire sample. The sample contains 19,817 firm-years. The median firm in the sample has 51 billion Lire ( $\$ 34$ million) in sales, a return on assets of 11 percent, a debt to capital ratio of 38 percent, and capital expenditures of 21 percent of net property plant and equipment. Retained earnings represent the main source of financing for the median firm, which does not pay any dividend, increasing its capital by $9 \%$ a year. External equity plays no role, while external debt adds only 2 percent to capital every year. Note that the number reported for market to book value is the median market to book value of equity for publicly traded companies in the same industry in each year. ${ }^{17}$

In evaluating the determinants and the effects of new listing it is important to take into account that every year only certain companies meet the listing requirements. Therefore, the appropriate benchmark against which we should compare the new listed firms is not the entire sample, but the sample of firms that did not list, despite meeting the listing requirements. As we previously mentioned, the listing requirements changed during the sample period.

In Table $3 \mathrm{~B}$ we report the summary statistics for all the company-years that satisfy the listing requirements as of that year. Not surprisingly, the median company in the sample is larger (60 billion Lire in sales), more profitable (the median return on assets is 14 percent), less levered (the median ratio of debt to capital is 33 percent) and invests more (24 percent). The median company in our sample is about four times as big as the typical U.S. IPO in terms of sales (Ritter, 1991).

Table $3 \mathrm{C}$ reports the summary statistics of the new listed companies as of the year they went public. It is interesting to note that the median IPO is twice as big as the median potential IPO in terms of sales, employees and total assets. By contrast, the median IPO is not more profitable

\footnotetext{
${ }^{17}$ Companies are divided in 23 industries according to the classification made by the Centrale dei Rischi. This roughly follows the SIC two digit division.
} 
than the median potential IPO and is more highly levered.

Finally, Table $3 \mathrm{D}$ reports some statistics on the age of new public companies and on the difference between their age and that of similar companies which stayed private (matched by sector, and within the sector by size). The average age of new public companies is 33,4 years for the companies which went public in 1982-92. These figures are roughly in line with those reported by Rydqvist and Högholm (1994) for other European countries, and much higher than the corresponding values for US new public companies: 6.7 years for venture-backed firms and 11 years for non-venture-backed firms (Gompers, 1992). Moreover, companies which go public appear to be significantly older than those which stay private: they were 10.4 years older in the 1980s and 17 years older in the earlier period! ${ }^{18}$ This is a loud reminder of the fact that in Italy the stock market does not cater to the financing needs of young businesses, as it does in the US.

\section{Analysis of the Ex Ante Determinants}

In analyzing the decision that leads a company to go public, we attack the problem from two different perspectives. In this section, we study whether it is possible to identify some variables that predict the listing decision. In doing this we build on the models briefly reviewed in section 1 . In the next section, we will study the effects of this decision on performance, financing, and cost of credit by comparing newly listed firms with a sample of similar firms that remained private even though they met the listing requirements.

In Table 1 we have identified some of the factors that may lead a company to go public. Larger companies should be more likely to go public because fixed costs are less important for them and informational asymmetries are less severe. The first explanatory variable we want to use, then, is an indicator of a company's size. We use the logarithm of sales as a measure of size. ${ }^{19}$

\footnotetext{
${ }^{18}$ This figure is not specific to the sample period investigated. To check this we collected the data for the age of companies which went public in the period 1968-81: the average IPO is even older (52.4 years), and significantly older than a matching company ( +17 years).

${ }^{19}$ Another prediction of the theory is that high-tech companies may be less willing to go public to protect their
} 
Table 1 also suggests that an IPO is more likely for companies in need for large amounts of external funds. A firm undertaking a large plan of investments or a firm facing high growth opportunities may find it more valuable to tap the public market as an alternative source of capital. As proxies for the demand for funds we use the lagged level of investments (measured as capital expenditure - hereafter CAPEX - over property plant and equipment) and the growth rate of sales. We expect them to have a positive effect on the probability of going public.

For the same reason we expect that the degree of leverage (the lagged value of total debt over total debt plus equity) will have a positive impact on the probability of going public. More highly levered companies should be more likely to face borrowing constraints and then need external equity capital they cannot easily raise privately, especially considering the lack of venture capital in Italy.

In contrast, gauging the effect of profitability is more difficult. First of all, profits are bound to be positively correlated with the likelihood of an IPO for regulatory reasons: as explained in section 3.2, only companies with three years of positive earnings can list on the Italian stock exchange. To avoid the distortion induced by this sample selection, we restrict our estimates to company-years that satisfy the listing requirements. But, even after controlling for this sample selection problem, the predicted effect of profitability remains ambiguous. On the one hand, a more profitable company needs less external equity, suggesting a negative impact of profitability on the probability of an IPO. On the other hand, a company experiencing a temporary surge in profits may go public hoping that investors will mistakenly perceive its high profitability as permanent and will overvalue its shares. In the latter case, one would expect profitability to have a positive impact on the probability of going public. We measure profitability as the lagged return on assets (earnings before interest, taxes, depreciation and amortization - hereafter EBITDA over total assets).

To the extent that entrepreneurs try to exploit the overvaluation of their companies by investors, one would also expect a company to be more likely to go public when the market for comparable companies is particularly buoyant. We measure the price that an IPO would fetch on

confidentiality. Given our limited number of IPOs we cannot test this hypothesis. 
the market by the median ratio of the market-to-book value of equity of public companies in the same industry. But a positive effect of the market-to-book value on the probability to go public is not necessarily driven by mispricing. A high market-to-book ratio may reflect a high present value of future growth opportunities in the corresponding sector. If these growth opportunities require large investments, companies will be induced to go public in order to raise the necessary funding. These two hypotheses cannot be discriminated on the basis of ex-ante evidence alone, but they can be distinguished by exploiting ex post evidence. We can claim that the relationship between market-to-book and IPOs is driven by the expectation of future growth opportunities only if we observe that new listed companies invest at an abnormal rate.

Finally, a company may be induced to tap public markets to reduce the bargaining power of its main bank. If this is an important factor, then an IPO should be more appealing for companies facing a higher cost of bank borrowing and a stronger concentration of its credit sources. We measure the relative cost of credit to company $i$ by $\mathrm{RCC}_{i t}=\left(1+r_{i t}\right) /\left(1+\bar{r}_{t}\right)$, i.e. the ratio between the interest factor charged to company $i$ at time $t, 1+r_{i t}$, and the average interest factor, $1+\bar{r}_{t}{ }^{20}$ The concentration of the company's credit is measured by the corresponding Herfindahl index of the lines of credit granted to a company by all banks. We expect that both of these variables have a positive impact on the probability of an IPO.

\subsection{Results on the entire sample}

In sum, we estimate the following probit model by maximum likelihood:

$$
\begin{gathered}
\operatorname{Pr}\left(\mathrm{IPO}_{i t}=1\right)=F\left(\alpha_{1} \text { SIZE }_{i t}+\alpha_{2} \text { CAPEX }_{i t}+\alpha_{3} \text { GROWTH }_{i t}+\alpha_{4} \text { ROA }_{i t}\right. \\
\left.+\alpha_{5} \text { LEVERAGE }_{i t}+\alpha_{6} \text { MTB }_{i t}+\alpha_{7} \text { RCC }_{i t}+\alpha_{8} \text { HERFINDAHL }_{i t}+\gamma_{t} \text { YEAR }_{t}\right)
\end{gathered}
$$

where IPO $\mathrm{It}_{i t}$ is a variable that equals 0 if company $i$ stays private in period $t$ and equals 1 if it goes public, $F(\cdot)$ is the cumulative distribution function of a standard normal variable, and

\footnotetext{
${ }^{20} \mathrm{~A}$ justification for this definition is provided in section 5.2 .
} 
$\mathrm{YEAR}_{t}$ is a calendar year dummy. At any time $t$ the sample includes all the private companies which in that year satisfy the listing requirements described in section $3.2 .{ }^{21}$ Of course, after a company went public we drop it from the sample. We have excluded from the sample the Italian subsidiaries of foreign corporations ( $14 \%$ of the sample), because no such company has ever gone public in Italy. ${ }^{22}$

Table 4 reports the estimates of this model, as well as heteroskedasticity-robust standard errors (the same is also true of subsequent tables). The first column of table 4 reports the estimates obtained by pooling independent companies and subsidiaries of listed companies. In other words, we do not distinguish between the IPOs of independent companies and carve-outs.

Not surprisingly, a company's size is an important determinant of an IPO. A one standard deviation increase in the logarithm of sales increases the probability of an IPO by one third of a percentage point. This corresponds to a $40 \%$ increase in the sample average probability of going public. This effect is statistically significant at the $1 \%$ level.

Both the variables that measure a firm's financing needs - investment and growth - increase the probability of listing, as expected. But the coefficient of investment is not statistically significant, while that of growth is only significant at the $10 \%$ level.

The proxies for the cost and availability of credit do not have much explanatory power either. Contrary to expectations, both the cost of bank credit and a firm's leverage have a negative impact on the likelihood of an IPO, but neither is statistically significant at the $10 \%$ level. By contrast, consistent with expectations, the concentration of bank credit appear to increase the likelihood of an IPO, but also this effect is not statistically significant.

Even when we restrict the sample to companies eligible to go public, profitability has a positive impact on the probability of going public, significant at the $10 \%$ level. A one standard deviation increase in profitability increases the probability of going public by one tenth of a

\footnotetext{
${ }^{21}$ Before 1989 the listing requirements could be waived at discretion by the CONSOB and we have no way to tell which companies could have obtained a waiver from the CONSOB. In our sample only two companies list without satisfying the requirements. Our qualitative results do not change if we include all the companies in the estimation.

${ }^{22}$ Anyway, including these companies does not materially affect our estimates.
} 
percentage point (roughly a $12 \%$ increase in the sample average probability of an IPO).

Finally, the industry market-to-book ratio appears to be the most significant determinant of the probability of listing, beside size. We find that a one-standard deviation increase in the market-to-book ratio raises the probability of listing of a firm in the same sector by one fifth of a percentage point, corresponding to a $25 \%$ increase in the sample average probability of going public. In our sample this translates into 16 more companies going public a year.

During the 1984-86 period new listings were given a temporary tax incentive. We analyze the effect of this tax incentive by testing whether, after controlling for other factors, IPOs are more likely in those three years. In the pooled sample, the probability of an IPO is 1.4 percentage points more likely in 1984-86 and this effect is statistically significant at the $5 \%$ level. At face value the impact of this tax incentive appears huge, especially if compared with the other estimated effects. However, we feel uncomfortable in attributing the entire effect of these year dummies to the tax incentive, since they may be capturing a time clustering of IPOs such as those identified by Ritter (1984). This alternative hypothesis is supported by the fact that the "hot market" also persists in 1987, despite the end of the tax incentive (the 1987 dummy is not significantly different from that of the preceding triennium).

One possible source of concern for the specification we adopted is that it ignores the possible existence of unobservable firm-specific effects, which might be correlated with our regressors. For example, practitioners talk about a "cultural resistance" of many entrepreneurs to take their companies public. If this entrepreneurial resistance is more widespread in more traditional businesses, which happen to be associated with low market-to-book value, then this cultural bias might account for the observed correlation between market-to-book and probability to go public. For this reason, we also estimated a linear probability model with firm-specific effects. The results (not reported) largely confirm our findings. In particular, the industry market-to-book ratio and the company's size remain the two most important determinants of an IPO. We also estimated (not reported) a proportional hazard ratio model of the probability a private firm going public for the 11 years at our disposition. It remains the case that the industry market-to-book ratio and the company's size are the two most significant factors underlying the probability of 
an IPO, while the level of profitability and the rate of growth lose statistical significance.

\subsection{Differences between independent IPOs and carve-outs}

Further insights on the determinants of IPOs can be obtained by dividing the sample between independent IPOs and carve-outs. It seems reasonable to assume that the factors underlying the decision of an independent company to go public are different from the factors which drive the decision of a subsidiary of a public company. This hypothesis is also supported by the data. A likelihood ratio test rejects at the $1 \%$ level the equality of the coefficients in the two subsamples.

The first striking fact is that size does not matter for carve-outs. ${ }^{23}$ The usual explanation for the importance of size is the existence of fixed flotation costs, which can be recovered only by firms above a certain threshold. A possible reason why size matters only for independent companies is that for subsidiaries the fixed costs of listing are partly sunk, being already borne by their parent company (as for the overhead costs of certification and dissemination of accounting information to the market). Another - possibly complementary - interpretation is that size acts as a proxy for reputation: small independent companies find it harder to get known to the public at large, whereas small subsidiaries of established public companies can draw upon the reputational capital of their parent company. As in Diamond (1991) and in Chemmanur and Fulghieri (1994), small companies find it difficult to establish a reputation and sell equity without paying a large adverse selection cost, unless they are subsidiaries of publicly traded companies.

A second difference is that both the estimated effects of profitability and of the market-tobook ratio of traded firms in the same industry appear approximately $50 \%$ bigger for carve-outs than for independent companies, although the difference is not statistically significant. A third difference concerns the role played by leverage. More highly levered companies are more likely to go public if they are independent, less if they are subsidiaries, but both effects are not statistically

\footnotetext{
${ }^{23}$ One may suspect that the lack of statistical significance of size in the carve-out sample derives simply from the fact that all the subsidiaries are above the minimum size required for listing. The average size of subsidiaries of publicly traded companies is indeed larger, but its range is not much different. To check that the different effect of size in carve-outs is not merely due to a different size distribution, we have re-estimated the regression by dropping the smaller firms from the sample of independent companies: size remains a significant determinant.
} 
significant.

A final difference regards investment and growth. Independent IPOs are companies that invested and grew more than the rest of the sample (both effects are statistically significant), as predicted by Pagano and Roell (1995). By contrast, carve-outs are subsidiaries that invested less than the rest and grew less (albeit only the first effect is statistically significant).

These findings may help identify the different motives behind a carve-out and a normal IPO. A carve-out is more likely to occur to exploit a favorable market valuation in its particular sector. This decision will be taken, though, only if the company is in sound economic and financial conditions. This explains the effects both of a high profitability and of a low leverage. An independent company may instead want to go public for need of equity capital, and this is more likely to be the case if the company is highly levered. This interpretation squares also with the much stronger impact of the industry market-to-book value on the probability of a carve-out: a group is much better at timing the market than an independent company. ${ }^{24}$

The picture that emerges so far is that carve-outs are driven by financial rather than real factors. This finding is consistent with evidence by Michaely and Shaw (1995) for the United States. Public companies carve out their most profitable subsidiaries in industries that trade at a premium with respect to their book value, independent of their size. By contrast, for independent companies size is the most important determinant of the decision to go public. For these companies, IPOs are more likely for high-growth companies, which invested a lot.

\section{Analysis of the Ex Post Consequences of an IPO}

An alternative strategy for uncovering the determinants of the decision to go public is to look at the effects of the IPO decision with respect to otherwise identical firms that chose to remain private. On the one hand, it is important to verify the truthfulness of the self-reported motives of the decision (see Ferrari, 1992), which stress the needs to finance investment and growth.

\footnotetext{
${ }^{24}$ It is interesting to point out that when we estimate a proportional hazard function (not reported) the marketto-book ratio is not statistically significant at the $5 \%$ level for independent companies, while it is significant at the $1 \%$ level for carve-outs.
} 
On the other hand, it is interesting to test whether the IPO has significant effects on operating performance and financing decisions. We investigate this by estimating fixed-effects regressions in which the effect of the decision to go public is captured by dummy variables for the year of the IPO and the three subsequent years. In estimating these regressions we face two sample selection problems.

First, only the companies which meet the listing requirements can go public. The performance of newly-listed companies may differ from that of private companies simply because they had to meet a profitability criterion before listing (for instance, their expected profitability will be higher if profits are positively autocorrelated). To correct for this sample selection problem, our regressors must include variables which capture the effect of meeting the listing requirements. To this purpose, we create four dummy variables, which at times $t$ equal 1 only if a company met the listing requirement at time $t, t-1, t-2$ and $t-3$ respectively. This presupposes that the effect of having met the listing requirement does not extend beyond three years.

Second, in estimating the ex-post consequences of IPOs, we face a potential endogenous selection problem: the companies which went public have chosen to do so. In principle this problem could be solved via a two-stage procedure, where the first stage involves estimating a model of the decision to go public such as equation (1) estimated in the previous section. Unfortunately, the very limited explanatory power of equation (1) eliminates the practical relevance of this procedure.

\subsection{Accounting Measures of Performance}

Table 5 reports the estimates of the effects of the IPOs on some operating and financial variables. For all the variable we use the following specification:

$$
y_{i t}=\alpha+\sum_{j=0}^{3} \beta_{j} I P O_{t-j}+\beta_{4} I P O_{t-n}+\sum_{j=0}^{3} \gamma_{j} Q U O T_{t-j}+u_{i}+d_{t}+\epsilon_{i t},
$$

where $u_{i}$ and $d_{t}$ are respectively a firm-specific and calendar year specific effect, $I P O_{t-j}$ are dummy variables equal to one if year $t-j$ was the IPO year, $I P O_{t-n}$ is a dummy variable equal 
to one if the IPO took place more than 3 years before, and $Q U O T_{t-j}$ are dummy variables equal to one if company $i$ satisfied the listing requirements in year $t-j$. By using a fixed effect model we are using a firm before the IPO as a control for itself after the IPO. The table only reports the coefficients on the IPO and post-IPO dummy variables.

Before presenting the results, it is worthwhile to discuss an obvious objection to our specification. Changes in accounting measures of performance may not hinge only on the decision to go public but also on other variables: for instance, profitability may depend also on lagged profitability, sales, investment, and so on. To control for these other variables, we have also estimated richer reduced-form models where the list of regressors also includes lagged values of the dependent variable and of other accounting variables that might be relevant "a priori". Since in most cases the results of these richer dynamic models are found to be qualitatively similar to those reported in Table 5, we do not report their estimates in a separate table, but we discuss them in what follows. We will make an exception only for the results on the cost of credit.

\subsubsection{Profitability}

The first row of the table shows that the profitability declines after the IPO. The effect increases gradually but steadily, rising from $1.5 \%$ less in the first year after the IPO to $3 \%$ in the third year and in subsequent years. The fall in profitability is statistically significant at the $1 \%$ level in each individual year. The permanent effect is even stronger for carve-outs $(-5 \%)$. This is consistent with the finding of Jain and Kini (1994) and Mikkelson, Partch, and Shah (1995).

As Degeorge and Zeckhauser (1993) point out, this result may be not all that surprising: entrepreneurs may time their issues to coincide with unusually high profitability or they may engage in "window-dressing" of their corporate accounts at the time of the IPO. According to this view this result is simply due to a normal regression to the mean. We have already partly addressed this potential criticism by inserting dummies when a company satisfied the listing requirements in previous years. These dummies, which are all negative and highly statistically significant, suggest that only a third of the observed $3 \%$ drop in profitability of IPOs can be explained by a normal regression to the mean. 
We try to probe this issue deeper, by adding to the list of regressors the first lag of profitability and the profitability in the year before the IPO. The first lag of profitability turns out to be very significant (with an estimated coefficient of .438 and a standard error of .14 ) but the coefficient of the profitability in the year before the IPO is small and imprecisely estimated. In this specification, the impact coefficient of the IPO dummy decreases further to -.011 and becomes significant at the $5 \%$ level, and those of the post-IPO dummies remain negative and significant at conventional levels. The long-run impact of each dummy is approximately equal to the respective coefficient in the first row of Table 5. The same is true if the regressors also include lagged investment and the log of lagged sales, which both enter the regression with significant coefficients. We conclude that the fall in profitability is really associated with the IPO, and does not result only from regression to the mean or from the effect of some other variable on profitability.

One possible explanation for this permanent drop in profitability has to do with the accounting changes brought by the decision to go public. In preparing their accounts for the IPO, a company has an interest in providing a fair (or even inflated) picture of the value of its assets. Such incentives are absent in private companies, which may be more concerned about hiding their value from the tax authority. ${ }^{25}$ As a result, the value of assets may be less undervalued (or more overvalued) in public companies than in private ones, correspondingly inflating the observed profitability. ${ }^{26}$

Other, more fundamental, explanations of the decline in profitability, are based on adverse selection (companies go public when profitability is about to decline permanently) or moral hazard (controlling shareholders have a greater incentive to extract private benefits at the expense of minority shareholders). In both cases, the relevant theoretical models predict that the fall in profitability will be larger for companies where the original entrepreneurs retain less equity: in

\footnotetext{
${ }^{25}$ The same reason, though, suggests that private companies are more likely to under-report profits, biasing the results against our finding.

${ }^{26}$ This problem might be particularly severe in Italy, where the high inflation rate of the 1970s and early $1980 \mathrm{~s}$ distorted the valuation of assets based on historical cost and where fiscal authorities periodically concede tax benefits to companies that voluntarily step up the book value of assets.
} 
the adverse selection model of Leland and Pyle, lower equity retention is a signal of bad quality, and in the moral hazard model by Jensen and Meckling (1976) it heightens the agency problem.

We can distinguish between the accounting and the two more fundamental explanations for post-IPO performance by examining the effect of the size of the incumbent's stake on a company's profitability after the IPO. If the accounting explanation is the right one, then we do not expect any relationship between the two. By contrast, if either the moral hazard or the adverse selection explanations are correct, then we expect a negative relationship. As we shall see in section 6, our evidence is most consistent with the second hypothesis.

\subsubsection{Investment and leverage}

Surprisingly, for independent companies the decision to go public has a negative impact on capital expenditures, as shown in the second row of Table 5. The decline in investment emerges with a delay of two years after the IPO but is large and permanent (a 7\% reduction of the capital stock). In contrast, carve-outs exhibit a significant temporary increase in investment at the time of the IPO ( $6 \%$ of the capital stock). These estimated effects persist when the regressors also include current profitability, external debt, external equity, and lagged investment, sales and profitability (all of which have positive and significant coefficients, except for lagged investment and sales).

Independent companies and carve-outs also differ markedly in the change of their leverage after the IPO, as illustrated by the third row of the table. Independent companies deleverage immediately, substantially (between $5 \%$ and $7 \%$ in the first four years) and permanently (by $9 \%$ ), while carve-outs do so only in the long run (also by $9 \%$ ). One may suspect that the finding that independent IPOs reduce their leverage after going public derives from their high profitability before the IPO (recall that there is a strong negative correlation between leverage and profitability, see for example Rajan and Zingales, 1995). But the result persists when one controls for lagged leverage, for current and lagged profitability (all highly significant) and for profitability in the year before the IPO (not significant).

If we consider these results together with those arising from our ex-ante analysis in section 4, 
a consistent story emerges. Recall that before the IPO, independent companies tend to display abnormally high investment and growth, while carve-outs have abnormally low investment and leverage. The ex-post evidence adds that after the IPO independent companies reduce their leverage and - with a lag - investment, while carve-outs step up investment temporarily at the time of the IPO and reduce leverage only later on. So independent companies tend to go public to rebalance their capital structure after implementing substantial investment plans, while carveouts occur to raise resources to finance current investment and, as we shall see later, to allow the controlling shareholder to divest partly from the company.

\subsubsection{Other accounting variables}

The results concerning the other accounting variables in Table 5 are less striking. Investment in financial assets rises temporarily at the time of the IPO, probably because the new public companies "park" temporarily the abnormal inflow of liquidity from the IPO in financial assets. Moreover, as one would expect, equity financing rises sharply (by 6\%) in the year of the IPO. There is no significant change in debt financing, payout and growth. The result about growth is at odds with the prototype of the IPO as a means to finance corporate growth, but squares with the above-reported results about investment (at least for the independent companies).

An interesting result is that new public companies appear to be subject to a permanent increase in tax pressure after the IPO: as a fraction of their operating income, they pay about $2 \%$ more taxes per year than before, although the effect is imprecisely estimated. This appears to provide some basis for the argument that the greater accounting transparency enforced by the stock exchange prevents companies from eluding or evading taxes, and that this represents one of the costs of going public. ${ }^{27}$

\footnotetext{
${ }^{27}$ We find another piece of evidence in favor of the view that tighter accounting standards entail greater tax pressure: if the regression is re-estimated after adding a dummy for Italian subsidiaries of foreign companies, which are presumably forced by their parent company to keep to strict accounting rules, one finds that these companies pay $2 \%$ more taxes than domestic companies.
} 


\subsection{Cost of credit}

One of the often claimed advantages of going public (Basile, 1988) is that this decision may improve the bargaining position vis-a-vis banks and other creditors. A formalization of this intuition is in Rajan (1992). Our access to a unique data set of rates offered by the largest 79 Italian banks to their clients allows us to test this hypothesis.

In measuring changes in the cost of credit we face two problems. First, we need to define properly what we mean with a change in the relative cost of credit during a period when the level of bank rates was extremely variable (the average rate oscillated between 12.95 and 22.76 percent). We chose to define the relative cost of credit of firm $i$ with respect to the average cost of credit as the ratio between the interest factor charged to company $i$ at time $t\left(1+r_{i t}\right)$ divided by the average interest factor charged to all the companies in the sample at that time $\left(1+\bar{r}_{t}\right) .{ }^{28}$ The appealing feature of this definition is that it is invariant to changes in the general level of interest rates. We also use (in unreported regressions) the difference between a firm's rate and the average rate as a measure of the relative cost of credit and we obtain results that are economically and statistically similar.

A second issue regards which interest rate should we use, given that all companies have a credit relationship with several banks. We chose to use the median rate charged to firm $i$ at time $t$ (defined as the last quarter of the year), because of its robustness to reporting errors. ${ }^{29}$ We have also tried a weighted average of the rates charged to each firm by its banks on all the outstanding credit lines, without significant changes in the results.

The estimates reported in Table 5 indicate a clear drop in the relative cost of credit of IPOs. This effect is statistically and economically significant in the IPO year and in the three subsequent years, while it weakens afterwards. The effect appears to be entirely concentrated

\footnotetext{
${ }^{28}$ This is the appropriate definition in a risk neutral world where differences in loan rates are solely determined by default risk. For instance, if company $i$ has a probability $\pi_{i}$ to default (and when defaults it does not pay anything back), then $1+r_{i t}$ equals $\frac{1+r_{i t}}{1-\pi_{i}}$, where $r_{f t}$ is the risk free rate at time $t$.

${ }^{29}$ The raw data report the quarterly payment (interest plus fixed fees) made by a firm to the bank and its quarterly average balance. Of course, using this data to compute the average interest rate will overestimate the rate of bank with a small average balance. For this reason, we eliminated the rates referring to credit lines with less than 50 million Lire (US\$ 34,000 ) in average daily balance.
} 
among independent IPOs. For these firms, we can reject the hypothesis that there are no changes in the cost of credit after an IPO at the $1 \%$ level, while we cannot reject it for carve-outs.

Although not huge, this effect is not trivial either, especially if we consider that IPOs already pays lower than average rate before they go public. The observed drop corresponds to a reduction in the rate of between 40 and 70 basis points. ${ }^{30}$ Considering that the average IPO has debt equal to Lire 99 billion (US $\$ 62 \mathrm{M}$ ), this reduction, if it applies to all debt, would produce Lire 495 million (US $\$ 309,000$ ) of savings per year. If permanent, this would imply a present value of savings of 3.1 billion Lire (US\$1.9M) - a sum larger than the direct costs of going public. ${ }^{31}$

There are at least three (possibly complementary) reasons why rates may fall after an IPO. First, upon listing companies may become safer borrowers because they reduce their leverage, as shown by Table 5 . Second, more information becomes publicly available about them, so that lenders spend less to collect information about their credit worthiness. Since by its very nature this information cannot be appropriated by any lender, banking competition will ensure that the lower information costs are rebated to borrowers in the form of lower interest rates. Third, being listed on the stock market offers to the company an outside financing option that curtails the bargaining power of banks as in Rajan (1992).

In Table 6 we analyze the post-IPO changes in the cost of credit while controlling for the changes in the fundamental risk characteristics of a company. As proxies for risk we use a company's size, its leverage, and its profitability. ${ }^{32}$ The estimated drop in the rates is only marginally reduced in this more complete specification. It remains true that independent IPOs exhibit an economically and statistically significant drop (30-55 basis points) in their cost of credit in the IPO year and in the three years afterward. The effect, however, is weaker ( 25 basis

\footnotetext{
${ }^{30}$ This is obtained by multiplying the coefficients (ranging between 0.0035 to 0.0062 ) by 1 plus the average bank rate during the period $(0.16)$.

${ }^{31}$ In Italy, the direct costs of going public are equal approximately to 380 million Lire (administrative costs) plus 3.5 percent of the gross proceeds (underwriting fees). So an IPO worth 50 billion Lire costs about 2.13 billion Lire, i.e. 4.3 percent of the gross proceeds (source: $l$ Sole 24 Ore, Special Insert "Guida alla quotazione", 29 July 1994, p. 24, based on estimates provided by the Stock Exchange Council).

${ }^{32}$ The estimates reported use the current level of profitability and leverage. We chose contemporaneous values because, as we previously saw, both profitability and leverage change significantly after the IPO and the rates we use refer to the last quarter, when most of these changes have probably already occurred. We also tried using lagged values of profitability and leverage, with no material changes in the results.
} 
points) and not statistically significant after the third year following an IPO and is not present at all in carve-outs.

Overall, Table 6 suggests that the drop in the cost of credit should not simply be attributed to an improvement in the credit worthiness of newly listed firms. Although we cannot exclude that an unobservable improvement in credit quality (not captured by our regressors) causes the drop, we regard this possibility as unlikely.

To support this view there are also the data on the concentration of credit (measured as the Herfindahl index of the lines of credit granted to a company by all its banks) and the number of banks with an outstanding line of credit toward an IPO firm. As the last two rows of Table 5 indicate, independent IPOs experience a reduction in the concentration of credit and an increase in the number of banks. The second effect is common to both subsamples, but is larger and statistically significant only for independent IPOs; the first one is present only in independent IPOs. Moreover, this effect appears mostly concentrated in the first three years after the IPO, along with the reduction in rates. In sum, these results suggest that there is more occurring around the IPO than a simple change in the credit quality of newly listed firms.

Distinguishing between the two other explanations - information and bargaining - would require a whole separate analysis (which we plan to undertake in future work). Nevertheless, it is worth mentioning one result consistent with the bargaining power explanation. A subsidiary of a publicly traded company probably enjoys the benefits of its parent bargaining position even before listing. This is also what surveyed companies seem to believe (Basile, 1988). Under the bargaining power hypothesis, thus, it is reasonable to expect that listing should have no effect on carve-out bank rates. This is indeed what we find.

\section{Ownership and control}

The change in the structure of ownership and in the controlling shareholder can offer important insights into the motives to go public. In particular, if the IPO is accompanied or followed by substantial divestment by the controlling shareholders or by surrender of control to outsiders, the 
likely motivation of the IPO is to allow the controlling shareholders to diversify their portfolio or increase consumption, rather than to tap fresh sources of finance for company investment. Changes in ownership structure can also improve our understanding of the effects of IPOs. For instance, models based on asymmetric information predict a positive correlation between a company's performance and the amount of equity divested by the initial owner at the IPO.

\subsection{Changes in ownership and control around the IPO date}

Table 7 reports ownership figures for the same sample of newly public companies used in the previous sections. Panel A of the figure displays statistics for the whole sample, and panels B and $\mathrm{C}$ report those for independent companies and carve-outs separately.

The figures in the top row of panel A show that the median percentage stake of the controlling group falls on average by 28 points at the time of the IPO and by 7 more points in the three subsequent years (21 and 5 percent respectively if one looks at mean values). However, the initial owners still retain much more than 50 percent of the shares, so that they do not take the full benefit of the diversification they could achieve without losing majority control. One might think that this is not the long term equilibrium level of ownership and that with time the large shareholder will further reduce his stake. However, the median large shareholder across all companies listed on the Milan Stock Exchange owns 55 percent of the voting rights (Fulghieri and Zingales, 1995). These two facts indicate that portfolio diversification reasons are not a primary reason behind an IPO and that the divestment of the large shareholder is mostly concentrated at the IPO.

To determine if the controlling shareholders have on balance divested from the company, the second row reports the change in the level of their stake scaled by the market value of the company at the time of the IPO. It turns out that indeed in the median case the controlling shareholders have cashed in 5.2 percent of the value of the company (11.3 percent if one looks at the mean value) at the time of the IPO, while no significant divestment can be detected in later years. But these descriptive statistics conceal who is doing what: the data reveal that in 39.8 percent of the cases the company raises new equity and the control group does not sell its equity 
at the time of the IPO, and in another 39.8 percent the company does not raise new equity and the control group sells some equity. Only in 11.7 percent of the cases does the company issue new equity while the control group decumulates. ${ }^{33}$ In fact, the correlation between the issue of new equity and the reduction of the control group's stake is -0.33 , and is significant at the 1 percent confidence level. So there are two quite distinct groups of companies in the sample: those where the control group keeps a strong financial commitment and demands new funds from outside investors, and those where it divests and does not raise new equity.

The third row shows that the newly quoted companies raise a substantial amount of fresh equity capital on the market, mostly at the time of the IPO (10.2 percent of their market value for the median company) and the fourth row indicates that the IPO is accompanied, not surprisingly, by a very large increase in the number of shareholders (over 1,000 times if one looks at median values). What is more surprising, is the substantial reduction in the number of shareholders in the subsequent three years (when over $1 / 3$ of the shareholders exit). This appears a rather unusual feature of the Italian market. ${ }^{34}$

In the three years after the IPO, the control group sells out the controlling stake to an outsider in 13.6 percent of the cases (bottom row). This figure shows that the turnover of control in newly quoted companies is about twice as high as in the Italian economy at large: the probability of a change in control over an horizon of three years is estimated to have been 7 percent in 1980-83 and 5.5 percent in 1986-90, employing a sample of 973 manufacturing firms used in the study by Barca et al. (1995). ${ }^{35} \mathrm{~A}$ chi-square test rejects at the $1 \%$ level the hypothesis that in privately held companies control is as likely to change hands as in new IPOs. This suggests that going public makes a change in control much more likely than it is for private companies, either because

\footnotetext{
${ }^{33}$ In 27 cases the control group sells equity and the company does not issue new equity. In another 27 cases the control group does not sell equity and the company issues new equity. In 8 cases the control group sells equity while the company issues new equity, while in 6 companies neither event happens.

${ }^{34}$ Because we were not aware of any study looking at this issue for other countries, we undertook an exploratory analysis of what happens in the U.S. We picked the first ten firm-commitment IPOs which took place in 1985 and we looked at the number of shareholders three years after. In all but one cases, the number of shareholders had increased (median increase 158 percent).

${ }^{35}$ Riccardo Cesari, one of the authors of that study, has kindly estimated this probability at our request, using the INVIND sample, which is well representative of the Italian manufacturing sector and contains a negligible number of public companies (34 out of 973).
} 
it facilitates a change in control or because it is chosen by controlling shareholders who want to sell out. This is consistent with Zingales (1995a), who sees control considerations as one of the main factors underlying the decision to go public.

Panels B and C show how the picture changes if one looks at the IPOs of independent companies and carve-outs separately. The significant differences are that $(i)$ in independent companies the control group starts out with a lower percentage stake than in carve-outs, (ii) controlling shareholders are less likely to divest at the time of the IPO (42 percent of the companies against 63 percent for carve-outs) and divests on average less (6.1 percent of the value of the company, to be compared with 17.9 percent for carve-outs), and (iii) controlling shareholders surrender control to outsiders less frequently (in only 10.5 percent of the cases versus 17.9 percent for carveouts). So divestment and reallocation of control play a much more important role in the decision to carve out a subsidiary than in the decision to list an independent company. This is consistent with the view that groups act more strategically in their decision to list their subsidiaries than independent companies in their choice to go public: groups appear to list their profitable, low-debt subsidiaries with superior market timing, and they often do this before transferring ownership and control over the subsidiary to a third party.

\subsection{Post-IPO decline in profitability and divestment by the con- trolling shareholder}

In section 5 we have seen that profitability falls substantially and permanently after the IPOs, and that this effect cannot be traced back only to mean reversion in profits nor to the effect of other lagged variables. It is natural, then, to ask if this fall in profitability can be attributed to the decline in the equity that the initial entrepreneur retains in the company. Such correlation may arise for two reasons. First, if the entrepreneur is better informed on the future value of the company and he uses the amount of equity retained as a signal of the company's value, then a negative correlation between accounting profitability and equity divestments arises as the outcome of a signaling game (see Leland and Pyle, 1977). Similarly, the reduction in the level of 
insiders' ownership may increase the agency costs between controlling shareholders and outside financiers, thus decreasing subsequent profitability (see Jensen and Meckling, 1976). To test this prediction, we regress the change in profitability (as measured by the change in the ROA) over a four-year interval after the IPO on the fraction of the total equity sold by the control group at the time of the IPO and on the increase in profitability occurring in the four years before the IPO. This specification is intended to nest the asymmetric information-agency model and the mean reversion hypothesis in the simplest possible way. The sample is limited to the companies which did go public, because we have no data on share ownership for private companies.

Table 8 reports the OLS estimates obtained regressing the change in profitability over the four-year interval after the IPO on a constant, the change in profitability before the IPO, and the fraction of equity sold by the control group at the IPO. The first column reports the estimates for the whole sample, while the second and third columns report the results for independent companies and carve-outs separately.

For the whole sample the coefficients for both the regressors have the expected sign (negative), but they are not precisely estimated and therefore they are not statistically significant. However, the pooled data disguise, as in numerous other occasions, two very different stories for the two subsamples. The divestment of the control group has no significant impact on subsequent performance for independent IPOs. By contrast, for carve-outs divestment by the control group has a negative and highly statistically significant effect on profitability, as found by Jain and Kini (1994) for US companies. Moreover, in both subsamples there is substantial evidence of mean reversion in profitability, a result already mentioned in subsection 5.1.1. The effect is stronger for carve-outs and is statistically significant only for them.

The effect predicted by Leland and Pyle (1977) and Jensen and Meckling (1976) is more pronounced in carve-outs rather than in independent IPOs. This finding is consistent with what we found in the rest of the paper. Carve-outs appear as pure financial operations designed to exploit strategically favorable market conditions and/or to increase the total proceeds from an eventual sale of a subsidiary. By contrast, the IPOs of independent companies respond more to the need to rebalance the corporate financial position after large investment and rapid growth. 
Because carve-outs appear more motivated by market timing, the parent company may have a greater need to signal its faith in the future value of the company by retaining a larger stake. This might explain why a negative correlation between equity divestment and profitability changes is observed only in carve-outs.

\section{Conclusions}

This paper investigates the determinants of the decision of a company to go public by comparing both the ex-ante and the ex-post characteristics of IPOs with those of a large sample of privately held companies of similar size. Our study identified several new facts, which raises a number of challenging questions that future research will have to address.

First, we find that the probability of an IPO is positively affected by the stock market valuation of firms in the same industry. This positive relationship may reflect a higher investment need in sectors with high growth opportunities (and correspondingly high market-to-book ratio) or the owners' attempt to exploit sectorial mispricing. Since investment decreases after IPOs, the weight of the evidence points to an explanation based on mispricing.

Second, we find that a company's size significantly affects the probability of listing, except for subsidiaries of publicly traded companies. In other words, there seems to be a fixed cost that a group (not a company) has to pay, to access the public market. The limited size of listing costs in Italy forces us to look elsewhere. One possible argument is the importance of reputation. This is, however, only a partial answer, because begs the question of why the Italian market requires a longer track record for newly listed firms. ${ }^{36}$ An alternative explanation is that there are other - often ignored - fixed costs of listing, as the implicit costs associated to a higher visibility to the tax and legal authorities. As the Financial Times recognizes "In Italy it is common knowledge

\footnotetext{
${ }^{36}$ One possible reason for why Italian companies need a higher reputational capital to go public is that the lack of enforcement of minority property rights in that country makes the magnitude of the potential agency problem much bigger. As Zingales (1994) argues, Italian companies find it easier to dilute the value of minority shareholders. This is also testified by extremely high value of control, an order of magnitude bigger than, for example, in the U.S. (Zingales, 1995b).
} 
most companies keep two sets of books and that tax evasion is widespread." (December 30, 1994, p4). Listing forces a company to have its accounts certified externally and this certainly increases the cost of keeping a parallel accounting system. Smaller independent firms may find it prohibitively expensive to set up such systems and for this reason avoid to tap the public market for equity financing. Unfortunately, it is very difficult to provide systematic evidence in this sense. We do find some evidence that the fiscal burden increases when companies go public, but this is not enough to prove our conjecture. A challenge for future research would be to assess empirically the validity of these arguments.

Third, we find that the cost of bank credit falls for newly listed companies. This drop is present even after controlling for firms' characteristics and for the reduction in leverage experienced after going public. Although we are currently unable to distinguish among the various possible explanations for this drop, the existing evidence leans more toward an increase in a firm's bargaining power vis-à-vis its banks (as in Rajan, 1992).

Fourth, we find that control changes hands in IPOs significantly more often than in privately held companies. This occurs despite the fact the controlling group always retains a large controlling block after the IPO. This finding is consistent with Zingales (1995a), who claims IPOs are undertaken to maximize the incumbent's proceeds from an eventual sale of the company.

Fifth, this study confirms the common wisdom that differentiates between independent IPOs and carve-outs. The picture that emerges is that carve-outs are mainly strategic financial operations designed to exploit favorable market conditions and/or to increase the total proceeds the parent company receives from an eventual sale of a subsidiary, even at the cost of increased agency problems. By contrast, independent IPOs occur in the wake of high investment and growth, as suggested by Pagano and Röell (1995).

Sixth, we find some evidence for a stock market role in rebalancing the company's accounts after a period of high investment and growth. This role is very different from that generally attributed to the stock market - i.e. financing future investments -, but nevertheless a very important one. An open question is to establish how much investments and growth would be reduced (if at all), were entrepreneurs deprived of the option to use the equity market to rebalance 
their accounts.

Finally, it is also interesting to mention what we do not find. Unlike U.S.-based studies (see Mikkelson, Partch and Shah, 1994), we do not find many young start-up companies that go public to finance their expansion. One important question for future research to address is why the Italian stock market does not absolve this financing role. Is it because small companies find other (more efficient) channels to finance their investments or because some of the above-mentioned reasons limit their access to the public equity market? 
Table 1:

\section{Empirical Predictions of the Main Theories Concerning the Decision to Go Public}

a: Costs of Going Public

\begin{tabular}{|c|c|c|c|}
\hline & \multirow[t]{2}{*}{ Model } & \multicolumn{2}{|c|}{ Empirical predictions } \\
\hline & & Effects on the probability of IPO & Consequences after IPO \\
\hline $\begin{array}{l}\text { Adverse selection } \\
\text { and moral hazard }\end{array}$ & $\begin{array}{l}\text { Leland and Pyle (1977), } \\
\text { Diamond (1991), Chemmanur } \\
\text { and Fulghieri (1994) }\end{array}$ & $\begin{array}{l}\text { Smaller and younger companies } \\
\text { less likely to go public }\end{array}$ & $\begin{array}{l}\text { Negative relation } \\
\text { between performance } \\
\text { and ownership }\end{array}$ \\
\hline Fixed costs & Ritter (1987) & $\begin{array}{l}\text { Smaller companies less likely } \\
\text { to go public }\end{array}$ & \\
\hline $\begin{array}{l}\text { Loss of } \\
\text { confidentiality }\end{array}$ & $\begin{array}{l}\text { Campbell (1979), } \\
\text { Yosha (1995) }\end{array}$ & $\begin{array}{l}\text { High-tech companies less likely } \\
\text { to go public }\end{array}$ & \\
\hline
\end{tabular}

\section{b: Benefits of Going Public}

\begin{tabular}{|c|c|c|c|}
\hline & \multirow[t]{2}{*}{ Model } & \multicolumn{2}{|c|}{ Empirical predictions } \\
\hline & & Effects on the probability of IPO & Consequences after IPO \\
\hline $\begin{array}{l}\text { Overcome borrowing } \\
\text { constraints }\end{array}$ & & $\begin{array}{l}\text { IPO more likely for high-debt/ } \\
\text { high-investment companies }\end{array}$ & $\begin{array}{l}\text { Deleveraging/ } \\
\text { high investment }\end{array}$ \\
\hline $\begin{array}{l}\text { Increase bargaining } \\
\text { power with banks }\end{array}$ & Rajan (1992) & $\begin{array}{l}\text { IPO more likely for companies } \\
\text { paying higher rates }\end{array}$ & $\begin{array}{l}\text { Decrease in borrowing } \\
\text { rates }\end{array}$ \\
\hline Diversification & Pagano (1993) & $\begin{array}{l}\text { Riskier companies more } \\
\text { likely to go public }\end{array}$ & $\begin{array}{l}\text { Controlling shareholder } \\
\text { decreases his stake }\end{array}$ \\
\hline $\begin{array}{l}\text { Stock market } \\
\text { monitoring }\end{array}$ & $\begin{array}{l}\text { Holmström and } \\
\text { Tirole (1993) }\end{array}$ & & $\begin{array}{l}\text { Large use of stock- } \\
\text { based incentive contracts }\end{array}$ \\
\hline Liquidity & $\begin{array}{l}\text { Pagano and } \\
\text { Röell (1995) }\end{array}$ & High-investment companies & Diffuse stock ownership \\
\hline $\begin{array}{l}\text { Enlarge set of } \\
\text { potential investors }\end{array}$ & Merton (1987) & & Diffuse stock ownership \\
\hline $\begin{array}{l}\text { Optimal way to } \\
\text { transfer control }\end{array}$ & Zingales (1995a) & & $\begin{array}{l}\text { Higher turnover of } \\
\text { control }\end{array}$ \\
\hline Exploit mispricing & De Long et al. (1990) & $\begin{array}{l}\text { High market-to-book values } \\
\text { in the relevant industry }\end{array}$ & $\begin{array}{l}\text { Underperformance } \\
\text { of IPOs }\end{array}$ \\
\hline
\end{tabular}


Figure 1:

\section{Number of Listed Companies and Real Stock Prices on the Milan Stock Exchange}

The time series of the stock price index is reconstructed following Panetta and Violi (1995). It is then deflated using the Consumer Price Index as computed by ISTAT. The number of listed companies is drawn from official publications of the Milan Stock Exchange Council.

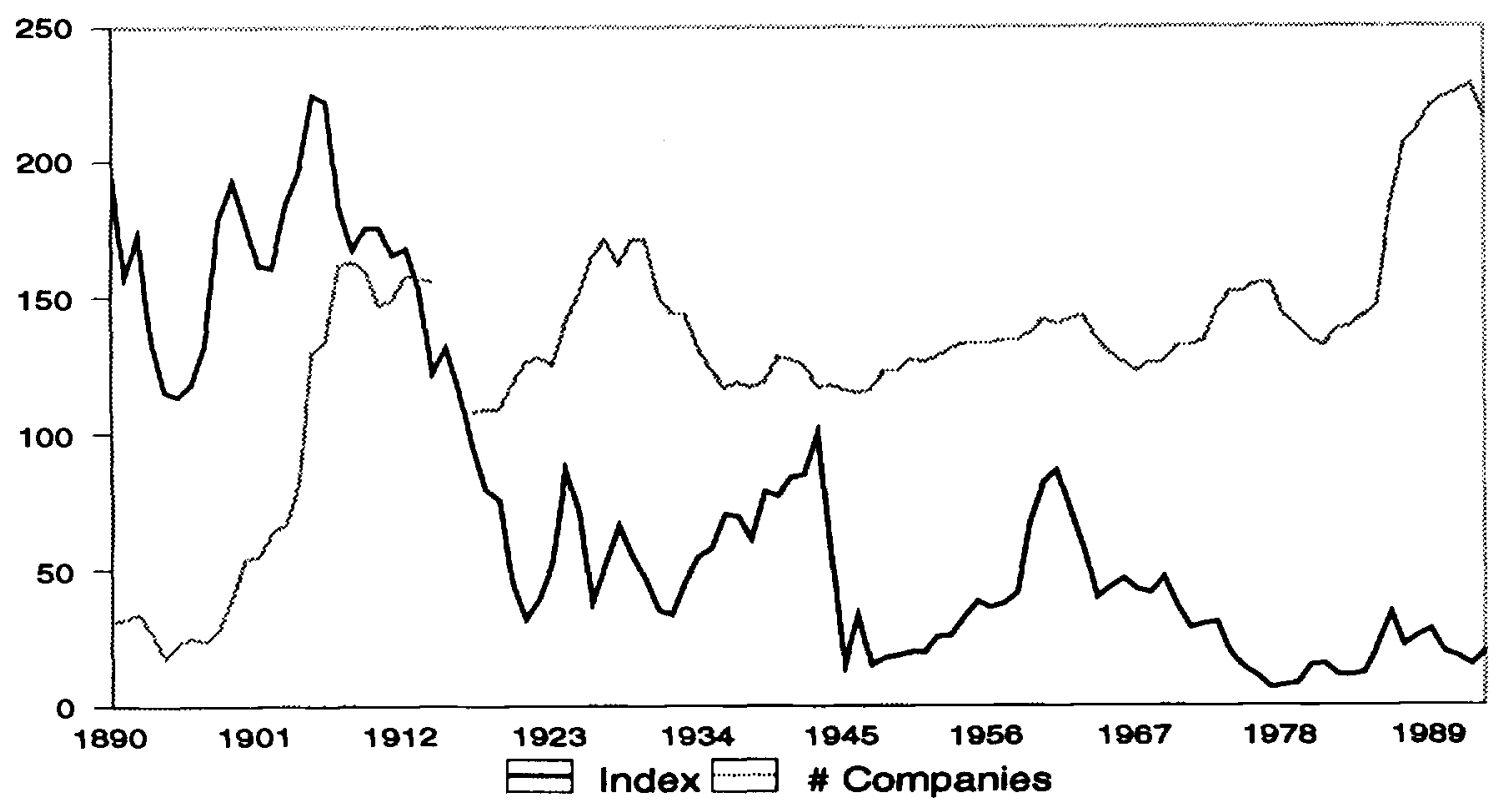


Table 2:

\section{Statistics on the Year of Listing}

Year of listing of companies in our sample according to the two definitions of listing. According to the first definition, a company goes public only when it becomes listed in the Milan Stock Exchange. According to the second definition, it goes public also when it enters a minor stock exchange (not located in Milan) or the second market ("Mercato Ristretto").

\begin{tabular}{|lrr|}
\hline Year & $\begin{array}{r}\text { Milan } \\
\text { Listings }\end{array}$ & $\begin{array}{r}\text { Any Market } \\
\text { Listings }\end{array}$ \\
1982 & 5 & 6 \\
1983 & 5 & 4 \\
1984 & 6 & 7 \\
1985 & 7 & 7 \\
1986 & 19 & 18 \\
1987 & 12 & 12 \\
1988 & 5 & 5 \\
1989 & 4 & 5 \\
1990 & 4 & 3 \\
1991 & 2 & 2 \\
1992 & 0 & 0 \\
\hline Total & 69 & 69 \\
\hline
\end{tabular}


Table 3:

\section{Summary Statistics}

In panel A the summary statistics refer to the entire sample, in panel B to the company-years that satisfy the official requirements for listing as of that year, in Panel $C$ to the companies which went public between 1982 and 1992, as of the year of their IPO. Note that the listing requirements changed during the sample period (see text). In panel $\mathrm{C}$ we lose three observations because the IPO-year contains some outliers (2 observations) and because the information for that company-year is not available from our dataset (1 observation). Panel $D$ reports the age since incorporation of IPOs and its difference with respect to a matching company, defined as the closest company in size (net sales) which belongs to the same industry. ROA is EBITDA (earnings before interest taxes and depreciation allowances) over total assets at the end of the previous year. ROS is EBITDA over revenues. Leverage is book value of short plus long term debt divided by book value of short plus long term debt plus book value of equity. Coverage is EBITDA divided by interest expenses (values above 100 are truncated at 100 , values below zero are truncated at zero). Taxes are taxes paid divided by operating income. The MTB is the median market to book value of equity of firms in the same industry which traded on the Milan Stock Exchange. Capex are capital expenditures over end of the year net property plant and equipment. Investment are financial investment divided by total assets. Equity financing is the equity issued divided by total capital (total debt plus equity). Debt financing are debt issues divided by total capital. Payout is dividend paid divided by net income by depreciation. The loan rate is the median interest rate paid by a firm on its lines of credit outstanding. The concentration of credit is the Herfindahl index of the credit lines outstanding.

A: The Whole Sample

\begin{tabular}{lcccccc}
\hline \hline Variable & Mean & Median & Std. Dev. & Min & Max & Obs. \\
Total Assets (Bill.) & 190 & 50.4 & 1,113 & 2.0 & 57,000 & 19,817 \\
Shareholders' Equity (Bill.) & 50.3 & 14.7 & 296.6 & -169 & 14000 & 19,817 \\
Sales (Bill.) & 1,741 & 50.7 & 768.5 & 0.036 & 27,300 & 19,817 \\
Employees & 737 & 258 & 3,251 & 0 & 108,662 & 19,817 \\
ROA & 0.12 & 0.11 & 0.11 & -1.0 & 1.21 & 19,817 \\
ROS & 0.12 & 0.11 & 0.20 & -2.49 & 2.23 & 19,817 \\
Leverage & 0.39 & 0.38 & 0.25 & 0 & 1 & 19,816 \\
Coverage & 8.19 & 2.77 & 17.15 & 0 & 100 & 19,766 \\
Taxes & 0.18 & 0.13 & 0.17 & 0 & 1 & 18,103 \\
Industry Market-to-Book & 1.39 & 1.29 & 0.62 & 0.34 & 5.85 & 18,268 \\
Capex & 0.25 & 0.21 & 0.20 & 0 & 1 & 18,263 \\
Investments & 0.023 & 0.008 & 0.09 & -0.99 & 0.93 & 19,808 \\
Equity Financing & 0.023 & 0 & 0.16 & -0.47 & 16.26 & 19,814 \\
Debt financing & 0.039 & 0.018 & 0.181 & -1.00 & 0.99 & 19,710 \\
Payout & 0.26 & 0 & 3.77 & 0 & 336.5 & 17,679 \\
Loan rate (\%) & 15.88 & 15.00 & 3.81 & 3.78 & 30.43 & 15,048 \\
Concentration credit & 0.19 & 0.13 & 0.18 & 0.02 & 1 & 19,118 \\
Number of banks & 13.9 & 11 & 11.3 & 0.0 & 134 & 19,274 \\
\hline \hline
\end{tabular}




\section{B: Sample Eligible to Go Public}

\begin{tabular}{lcccccc}
\hline \hline Variable & Mean & Median & Std. Dev. & Min & Max & Obs \\
Total Assets (Bill.) & 222.5 & 59.9 & $1,350.3$ & 5.8 & 57,000 & 12,391 \\
Shareholders' Equity (Bill.) & 62.9 & 18.8 & 363.6 & -33.7 & 14,000 & 12,391 \\
Sales (Bill.) & 1,935 & 61.1 & 835.9 & 0.036 & 27,300 & 12,391 \\
Employees & 865 & 307 & 3772 & 0 & 108,662 & 12,391 \\
ROA & 0.14 & 0.13 & 0.10 & -0.93 & 1.21 & 12,391 \\
ROS & 0.14 & 0.12 & 0.17 & -2.48 & 2.23 & 12,391 \\
Leverage & 0.35 & 0.33 & 0.23 & 0 & 1 & 12,391 \\
Coverage & 9.56 & 3.28 & 18.76 & 0 & 100 & 12,352 \\
Taxes & 0.20 & 0.18 & 0.17 & 0 & 1.00 & 11,632 \\
Industry Market-to-Book & 1.35 & 1.25 & 0.62 & 0.34 & 5.85 & 11,365 \\
Capex & 0.28 & 0.24 & 0.21 & 0 & 0.99 & 10,937 \\
Investments & 0.03 & 0.01 & 0.09 & -0.96 & 0.93 & 12,388 \\
Equity Financing & 0.02 & 0 & 0.06 & -0.47 & 1.30 & 12,391 \\
Debt financing & 0.04 & 0.016 & 0.17 & -1.00 & 0.99 & 12,345 \\
Payout & 0.31 & 0.06 & 4.56 & 0 & 336.5 & 10,621 \\
Loan rate (\%) & 16.42 & 15.59 & 4.23 & 3.78 & 30.44 & 9,285 \\
Concentration credit & 0.19 & 0.13 & 0.18 & 0.02 & 1 & 12,040 \\
Number of banks & 14.6 & 12 & 11.86 & 0.0 & 134 & 12,148 \\
\hline \hline
\end{tabular}

C: The IPO Sample

\begin{tabular}{lcccccc}
\hline \hline Variable & Mean & Median & Std. Dev. & Min & Max & Obs \\
Total Assets (Bill.) & 440.8 & 163.3 & $888,013.6$ & 11.6 & $6,234.7$ & 66 \\
Shareholders' Equity (Bill.) & 138.3 & 48.2 & 360.5 & 7.5 & $2,790.0$ & 66 \\
Sales (Bill.) & 257.2 & 123.5 & 352.7 & 3.5 & 1,737 & 66 \\
Employees & $1,447.7$ & 759.5 & 2,190 & 3 & 12,906 & 66 \\
ROA & 0.14 & 0.13 & 0.85 & 0.002 & 0.40 & 66 \\
ROS & 0.19 & 0.15 & 0.12 & 0.01 & 0.52 & 66 \\
Leverage & 0.38 & 0.40 & 0.24 & 0 & 0.81 & 66 \\
Coverage & 10.24 & 3.80 & 18.51 & 1 & 100 & 66 \\
Taxes & 0.21 & 0.21 & 0.13 & 0.01 & 0.60 & 65 \\
Industry Market-to-Book & 1.66 & 1.25 & 0.55 & 0.75 & 2.89 & 66 \\
Capex & 0.35 & 0.31 & 0.21 & 0.00 & 0.87 & 64 \\
Investments & 0.09 & 0.05 & 0.12 & -0.15 & 0.49 & 66 \\
Equity Financing & 0.09 & 0.003 & 0.16 & 0.00 & 0.68 & 66 \\
Debt financing & 0.06 & 0.032 & 0.20 & -0.38 & 0.79 & 66 \\
Payout & 0.30 & 0.22 & 0.37 & 0.00 & 2.79 & 65 \\
Loan rate (\%) & 14.25 & 13.00 & 3.18 & 8.99 & 21.76 & 60 \\
Concentration credit & 0.11 & 0.08 & 0.13 & 0.03 & 1 & 63 \\
Number of banks & 23.4 & 23 & 13.5 & 0.0 & 59 & 65 \\
\hline \hline
\end{tabular}




\section{D: Age of IPOs}

\begin{tabular}{lcccccc}
\hline \hline Variable & Mean & Median & Std. Dev. & Min. & Max & Obs. \\
Age & 33.43 & 26 & 28.31 & 3 & 144 & 68 \\
Age Difference & 10.38 & 3 & 29.54 & -57 & 93 & 68 \\
\hline \hline
\end{tabular}


Table 4:

\section{Determinants of the Decision to Go Public}

The effect of the variables listed on the probability to go public is estimated by a probit model. The estimation method is maximum likelihood. The dependent variable is 0 if the company is not listed and 1 on the year of listing (observation for public companies are dropped from the sample). The sample is restricted to all companiesyears which satisfy the listing requirement as of that year. Subsidaries of foreign corporations are excluded from the sample. The independent-IPO sample excludes all subsidiaries of publicly traded companies from the sample, while the carve-out sample is restricted to subsidiaries of publicly traded companies. Sales is the lagged value of the logarithm of revenues. Capex is the lagged value of capital expenditures over Property Plant and Equipment. Growth is the rate of growth of sales in that year. ROA is the lagged value of EBITDA over total assets. Leverage is the lagged value of the ratio of the book value of short plus long term debt divided by book value of short plus long term debt plus book value of equity the year before. Bank rate is the lagged value of the relative cost of borrowing for firm $i$ relative to the average borrowing rate of all the firms in the sample. The concentration of borrowing is the lagged vale of the Herfindahl index of the lines of credit granted by different banks. The industry MTB is the median market to book value of equity of firms in the same industry which traded on the Milan Stock Exchange. The regression includes also a constant term and calendar year dummies (not reported). Heteroskedasticity robust standard errors are in brackets. The tax effect is the average value of the calendar year dummies in the three years when there was a tax incentive to go public. The p-value of an F-test for the hypothesis that the joint effect of these three variables equals zero is also reported.

\begin{tabular}{lccc}
\hline \hline Variable & Whole sample & Independent IPOs & Carve-outs \\
Sales & $0.202^{* * *}$ & $0.230^{* * *}$ & -0.070 \\
& $(0.044)$ & $(0.055)$ & $(0.088)$ \\
Capex & 0.167 & $0.343^{* *}$ & -0.770 \\
& $(0.180)$ & $(0.169)$ & $(0.528)$ \\
Growth & $0.234^{*}$ & $0.322^{* *}$ & -0.428 \\
& $(0.131)$ & $(0.150)$ & $(0.415)$ \\
ROA & $0.791^{*}$ & $1.170^{* *}$ & $1.768^{*}$ \\
& $(0.449)$ & $(0.485)$ & $(1.045)$ \\
Leverage & -0.032 & 0.183 & -0.596 \\
& $(0.277)$ & $(0.317)$ & $(0.492)$ \\
Bank Rate & -4.093 & 5.070 & -16.156 \\
& $(5.535)$ & $(4.460)$ & $(12.424)$ \\
Concentration & 0.151 & -0.668 & -0.193 \\
of Borrowing & $(0.575)$ & $(0.832)$ & $(0.731)$ \\
Industry MTB & $0.241^{* * *}$ & $0.206^{* *}$ & $0.333^{* *}$ \\
& $(0.065)$ & $(0.081)$ & $(0.174)$ \\
N. Obs. & 5,350 & 4,919 & 431 \\
Pseudo- $R^{2}$ & 0.100 & 0.143 & 0.131 \\
\hline Tax Effect & 0.511 & 0.854 & 0.176 \\
& 0.050 & 0.011 & 0.500 \\
\hline
\end{tabular}

**** indicates the coefficient is significantly different from zero at the $1 \%$ level or less;

** indicates the coefficient is significantly different from zero at the $5 \%$ level;

* indicates that the coefficient is significantly different from zero at the $10 \%$ level 
Table 5:

\section{Effects of the Decision to Go Public}

For each of the variables listed we estimate the following specification:

$$
y_{i t}=\alpha+\sum_{j=0}^{3} \beta_{j} I P O_{t-j}+\beta_{4} I P O_{t-n}+\sum_{j=0}^{3} \gamma_{j} Q U O T_{t-j}+u_{i}+d_{t}+\epsilon_{i t}
$$

where $u_{i}$ and $d_{t}$ are respectively a firm-specific and calendar year specific effect, $I P O_{t-j}$ are dummy variables equal to one if year $t-j$ was the IPO year, $I P O_{t-n}$ is a dummy variable equal to one if IPO took place more than 3 years before, and $Q U O T_{t-j}$ are dummy variables equal to one if year company $i$ satisfied the listing requirements in year $t-j$. By using a fixed effect model we are using a firm before the IPO as a control for itself after the IPO. The table only reports the coefficients on the IPO and post-IPO dummy variables. The independent sample excludes all subsidiary of publicly traded companies from the sample, while the carve-out sample is restricted to subsidiaries of publicly traded companies. ROA is EBITDA over total assets at the end of the previous year. Capex are capital expenditures over property plant and equipment during the previous year. Investment are financial investment divided by total assets. Leverage is book value of short plus long term debt divided by book value of short plus long term debt plus book value of equity. Equity financing is the equity issued divided by total capital (total debt plus equity). Debt financing are debt issues divided by total capital. Payout is dividend paid divided by net income by depreciation. Taxes are taxes paid divided by operating income. Growth is the rate of growth of sales in that year. Interest rate is the relative cost of credit of firm $i$ measured as one plus the median rate paid on all the outstanding credit lines divided by one plus the average rate paid by all firms in the sample during that year. The concentration of credit is the Herfindahl index of the credit lines outstanding. The number of banks is the number of banks with a credit line outstanding. Heteroskedasticity robust standard errors are reported in brackets. The the last column reports the p-value for the hypothesis that the sum of the coefficients of all the post-IPO dummies are equal to zero. The superscript ** indicates that the coefficient is significantly different from zero at the $5 \%$ level or less; the superscript * indicates that the coefficient is significantly different from zero at the $10 \%$ level.

\begin{tabular}{l|ccccccc}
\hline \hline & Sample Used & Year 0 & Year +1 & Year +2 & Year +3 & Year > 3 & F-test \\
\hline \multirow{4}{*}{ ROA } & & & & & & & \\
& Whole sample & -.008 & $-.015^{* *}$ & $-.020^{* *}$ & $-.028^{* *}$ & $-0.031^{* *}$ & .000 \\
& & $(.006)$ & $(.006)$ & $(.007)$ & $(.007)$ & $(.005)$ & \\
& Independent & -.009 & -.010 & $-.029^{* *}$ & $-.036^{* *}$ & $-.027^{* *}$ & .000 \\
& & $(.008)$ & $(.007)$ & $(.009)$ & $(.010)$ & $(.008)$ & \\
& Carve-outs & -.009 & $-.029^{* *}$ & $-.018^{*}$ & $-.029^{* *}$ & $-.048^{* *}$ & .000 \\
& & $(.010)$ & $(.010)$ & $(.010)$ & $(.009)$ & $(.009)$ & \\
\hline \multirow{4}{*}{ CAPEX } & Whole sample & .023 & .016 & -.017 & $-.041^{* *}$ & $-.042^{* *}$ & .304 \\
& & $(.018)$ & $(.017)$ & $(.018)$ & $(.016)$ & $(.016)$ & \\
& Independent & -.010 & -.009 & -.027 & $-.091^{* *}$ & $-.070^{* *}$ & .017 \\
& & $(.023)$ & $(.023)$ & $(.027)$ & $(.022)$ & $(.022)$ & \\
& \multirow{2}{*}{ Carve-outs } & $.064^{* *}$ & .028 & .002 & .032 & .010 & .136 \\
& & $(.027)$ & $(.027)$ & $(.023)$ & $(.024)$ & $(.024)$ & \\
\hline \hline
\end{tabular}




\begin{tabular}{|c|c|c|c|c|c|c|c|}
\hline & Sample Used & Year 0 & Year +1 & Year +2 & Year +3 & Year > 3 & F-test \\
\hline \multirow{5}{*}{ Leverage } & Whole sample & $-.051^{*}$ & -.031 & $-.054^{* *}$ & $-.064^{* *}$ & $-.116^{* *}$ & .000 \\
\hline & & $(.021)$ & $(.022)$ & $(.018)$ & $(.18)$ & $(.014)$ & \\
\hline & Independent & $-.070^{* *}$ & $-.047^{*}$ & $-.048^{* *}$ & $-.050^{* *}$ & $-.094^{* *}$ & .000 \\
\hline & & $(.027)$ & $(.026)$ & $(.024)$ & $(.025)$ & $(.019)$ & \\
\hline & Carve-outs & -.002 & .022 & -.015 & -.036 & $-.095^{* *}$ & .016 \\
\hline \multirow{5}{*}{$\begin{array}{l}\text { Financial } \\
\text { Investments }\end{array}$} & Whole samole & $\frac{(.033)}{024^{*}}$ & $\frac{(.037)}{002}$ & $\frac{(.027)}{0.077}$ & $\frac{(.026)}{015}$ & $(.224)$ & \\
\hline & Prifule sangit & $(.015)$ & $(.015)$ & $\begin{array}{l}-.007 \\
(.012)\end{array}$ & $\begin{array}{l}-.015 \\
(.013)\end{array}$ & $\begin{array}{l}-.006 \\
(.011)\end{array}$ & .949 \\
\hline & Independent & .013 & .001 & .003 & $-.032^{* *}$ & .001 & .704 \\
\hline & & $(.016)$ & $(.015)$ & $(.014)$ & $(.012)$ & $(.014)$ & \\
\hline & Carve-outs & $\begin{array}{c}.039 \\
(.026)\end{array}$ & $\begin{array}{l}.010 \\
(.030)\end{array}$ & $\begin{array}{c}-.019 \\
(.021)\end{array}$ & $\begin{array}{l}-.004 \\
(.026)\end{array}$ & $\begin{array}{l}-.027 \\
(.021)\end{array}$ & .999 \\
\hline \multirow{3}{*}{$\begin{array}{l}\text { Equity } \\
\text { Financing }\end{array}$} & Whole sample & $\begin{array}{l}.062^{* *} \\
(.019)\end{array}$ & $\begin{array}{l}.010 \\
(.010)\end{array}$ & $\begin{array}{c}.004 \\
(.012)\end{array}$ & $\begin{array}{l}.005 \\
(.013)\end{array}$ & $\begin{array}{l}-.004 \\
(.010)\end{array}$ & .063 \\
\hline & Independent & $.067^{* *}$ & $\begin{array}{l}.004 \\
(.013)\end{array}$ & $\begin{array}{c}.007 \\
(.014)\end{array}$ & $\begin{array}{l}-.002 \\
(.015)\end{array}$ & $\begin{array}{c}.002 \\
(.014)\end{array}$ & .136 \\
\hline & Carve-outs & $\begin{array}{c}.048 \\
(.034)\end{array}$ & $\begin{array}{c}.018 \\
(.019)\end{array}$ & $\begin{array}{l}-.002 \\
(.022)\end{array}$ & $\begin{array}{l}.014 \\
(.024)\end{array}$ & $\begin{array}{l}-.010 \\
(.015)\end{array}$ & .320 \\
\hline \multirow{3}{*}{$\begin{array}{l}\text { Debt } \\
\text { Financing }\end{array}$} & Whole sample & $\begin{array}{c}.003 \\
(.027)\end{array}$ & $\begin{array}{c}.014 \\
(.025)\end{array}$ & $\begin{array}{c}-.001 \\
(.025)\end{array}$ & $\begin{array}{l}-0.007 \\
(.022)\end{array}$ & $\begin{array}{r}-0.021 \\
(.018)\end{array}$ & .886 \\
\hline & Independent & $\begin{array}{c}.016 \\
(.038)\end{array}$ & $\begin{array}{c}.019 \\
(.031)\end{array}$ & $\begin{array}{c}.031 \\
(.032)\end{array}$ & $\begin{array}{c}-.022 \\
(.024)\end{array}$ & $\begin{array}{r}-.030 \\
(.024)\end{array}$ & .892 \\
\hline & Carve-outs & $\begin{array}{l}-.024 \\
(.037)\end{array}$ & $\begin{array}{l}.005 \\
(.044)\end{array}$ & $\begin{array}{l}-.042 \\
(.040)\end{array}$ & $\begin{array}{r}-0.008 \\
(.034)\end{array}$ & $\begin{array}{r}-0.032 \\
(.033)\end{array}$ & .457 \\
\hline \multirow{3}{*}{ Payout } & Whole sample & $\begin{array}{l}-.001 \\
(.085)\end{array}$ & $\begin{array}{l}-.053 \\
(.085)\end{array}$ & $\begin{array}{l}-.055 \\
(.077)\end{array}$ & $\begin{array}{l}-.041 \\
(.098)\end{array}$ & $\begin{array}{l}-.052 \\
(.131)\end{array}$ & .609 \\
\hline & Independent & -.060 & -.009 & -106 & -.020 & -.184 & .382 \\
\hline & Carve-outs & $\begin{array}{c}(.111) \\
-.097 \\
(.192)\end{array}$ & $\begin{array}{c}(.119) \\
-.212 \\
(.237)\end{array}$ & $\begin{array}{c}(.090) \\
.013 \\
(.184)\end{array}$ & $\begin{array}{r}(.135) \\
-0.094 \\
(.319)\end{array}$ & $\begin{array}{l}(.146) \\
0.069 \\
(.438)\end{array}$ & .757 \\
\hline \multirow{3}{*}{ Taxes } & Whole sample & $\begin{array}{l}.021 \\
(.012)\end{array}$ & $\begin{array}{c}.018 \\
(.017)\end{array}$ & $\begin{array}{c}.025 \\
(.019)\end{array}$ & $\begin{array}{c}.014 \\
(.021)\end{array}$ & $\begin{array}{c}.018 \\
(.014)\end{array}$ & .050 \\
\hline & Independent & $\begin{array}{l}.014 \\
(.015)\end{array}$ & $\begin{array}{c}.009 \\
(.024)\end{array}$ & $\begin{array}{l}.014 \\
(.024)\end{array}$ & $\begin{array}{l}-.034 \\
(.025)\end{array}$ & $\begin{array}{l}.018 \\
(.020)\end{array}$ & .736 \\
\hline & Carve-outs & $\begin{array}{c}.027 \\
(.021)\end{array}$ & $\begin{array}{c}.022 \\
(.025)\end{array}$ & $\begin{array}{c}.029 \\
(.029)\end{array}$ & $\begin{array}{c}.057 \\
(.035)\end{array}$ & $\begin{array}{l}.005 \\
(.024)\end{array}$ & .101 \\
\hline \multirow{3}{*}{ Growth } & Whole sample & $\begin{array}{c}.031 \\
(.023)\end{array}$ & $\begin{array}{c}.029 \\
(.021)\end{array}$ & $\begin{array}{l}-.003 \\
(.022)\end{array}$ & $\begin{array}{c}.015 \\
(.026)\end{array}$ & $\begin{array}{c}.005 \\
(.019)\end{array}$ & .282 \\
\hline & Independent & $\begin{array}{l}.016 \\
(.036)\end{array}$ & $\begin{array}{c}.017 \\
(.029)\end{array}$ & $\begin{array}{l}-.040 \\
(.031)\end{array}$ & $\begin{array}{l}-.023 \\
(.036)\end{array}$ & $\begin{array}{c}.016 \\
(.027)\end{array}$ & .898 \\
\hline & Carve-outs & $\begin{array}{l}.038 \\
(.029)\end{array}$ & $\begin{array}{c}.038 \\
(.031)\end{array}$ & $\begin{array}{l}.045 \\
(.031)\end{array}$ & $\begin{array}{l}.051 \\
(.037)\end{array}$ & $\begin{array}{l}-.046 \\
(.032)\end{array}$ & .260 \\
\hline \multirow{3}{*}{$\begin{array}{l}\text { Interest } \\
\text { rate }\end{array}$} & Whole sample & $\begin{array}{l}.0023^{* *} \\
(.0011)\end{array}$ & $\begin{array}{l}-.0016 \\
(.0012)\end{array}$ & $\begin{array}{c}-.0038^{* * *} \\
(.0014)\end{array}$ & $\begin{array}{c}-.0034^{* * *} \\
(.0013)\end{array}$ & $\begin{array}{l}-.0016 \\
(.0011)\end{array}$ & .005 \\
\hline & Independent & $\begin{array}{l}.0035^{* *} \\
(.0015)\end{array}$ & $\begin{array}{c}-.0035^{* *} \\
(.0018)\end{array}$ & $\begin{array}{c}-.0060^{* *} \\
(.0020)\end{array}$ & $\begin{array}{c}-.0062^{* * *} \\
(.0019)\end{array}$ & $\begin{array}{l}-.0025 \\
(.0016)\end{array}$ & .001 \\
\hline & Carve-outs & $\begin{array}{c}-.0006 \\
(.0017)\end{array}$ & $\begin{array}{c}-.0003 \\
(.0017)\end{array}$ & $\begin{array}{c}-.0021 \\
(.0018)\end{array}$ & $\begin{array}{c}-.0001 \\
(.0016)\end{array}$ & $\begin{array}{c}-.0009 \\
(.0017)\end{array}$ & .535 \\
\hline
\end{tabular}




\begin{tabular}{l|ccccccc}
\hline & Sample Used & Year 0 & Year +1 & Year +2 & Year +3 & Year > 3 & F-test \\
\hline & Whole sample & -0.002 & -0.058 & -0.013 & $-0.025^{*}$ & 0.010 & .372 \\
Concentration & & $(.008)$ & $(.011)$ & $(.016)$ & $(.009)$ & $(.011)$ & \\
of credit & Independent & -.005 & $-.025^{* *}$ & $-0.040^{* *}$ & $-0.049^{* *}$ & $-0.026^{* *}$ & .000 \\
& & $(.010)$ & $(.006)$ & $(.008)$ & $(.010)$ & $(.009)$ & \\
& Carve-outs & .006 & 0.022 & 0.026 & -.005 & 0.031 & .370 \\
& & $(0.014)$ & $(0.025)$ & $(0.038)$ & $(0.020)$ & $(0.026)$ & \\
\hline \multirow{4}{*}{$\begin{array}{l}\text { Number of } \\
\text { banks }\end{array}$} & Whole sample & $1.47^{* *}$ & $2.28^{* *}$ & $3.16^{* *}$ & $3.25^{*}$ & -.002 & .000 \\
& & $(.578)$ & $. .636)$ & $(.685)$ & $(.777)$ & $(.597)$ & \\
& Independent & $2.13^{* *}$ & $3.67^{* *}$ & $4.92^{* *}$ & $4.77^{* *}$ & $1.92^{* *}$ & .000 \\
& & $(.610)$ & $(.780)$ & $(.879)$ & $(1.003)$ & $(.629)$ & \\
& Carve-outs & .654 & .944 & 1.637 & $2.488^{* *}$ & -.349 & .149 \\
& & $(1.082)$ & $(1.054)$ & $(1.073)$ & $(1.234)$ & $(1.113)$ & \\
\hline \hline
\end{tabular}


Table 6:

\section{The Effect of an IPO on Bank Rates}

We estimate the effect of an IPO on the cost of credit with a within estimator. The cost of credit is defined as $\frac{1+r_{i t}}{1+r_{t}}$, where $r_{i t}$ is the median rate across all banks paid by firm $i$ in year $t$ and $\bar{r}_{t}$ is the cross sectional average of rates charged to the firms in the sample in year $t$. A separate dummy is inserted in the IPO year and the following three years. We then have a dummy which equals 1 in all the firm-years following the third year after the IPO, and 0 otherwise. We control for the selection bias generated by the listing requirements by inserting four analogous dummies (not reported) if a company satisfied the listing requirements respectively that year, the year before, two years before, and three years before. We also insert calendar year dummies (not reported). Besides these dummies we include as a regressors the level of profitability (ROA is EBITDA over total assets), leverage (book value of short plus long term debt divided by book value of short plus long term debt plus book value of equity) and the company's size (logarithm of sales). Heteroskedasticity robust standard errors are reported in brackets.

\begin{tabular}{lccc}
\hline \hline & Whole sample & Independent & Carve-outs \\
ROA & .0010 & 0.0015 & -0.0087 \\
& $(0.0019)$ & $(0.0020)$ & $(0.0054)$ \\
Leverage & $0.0041^{* * *}$ & $0.0049^{* * *}$ & -0.0044 \\
& $(0.0008)$ & $(0.0009)$ & $(0.0024)$ \\
Size & $-0.0022^{* * *}$ & $-0.0021^{* * *}$ & $-0.0043^{* * *}$ \\
& $(0.0003)$ & $(0.0003)$ & $(0.0010)$ \\
IPO year & -0.0017 & $-0.0028^{*}$ & -0.0001 \\
& $(0.0011)$ & $(0.0015)$ & $(0.0016)$ \\
IPO year +1 & -0.0010 & $-0.0029^{*}$ & 0.0008 \\
& $(0.0012)$ & $(0.0018)$ & $(0.0018)$ \\
IPO year +2 & -0.0022 & $-0.0047^{* *}$ & 0.0005 \\
& $(0.0014)$ & $(0.0020)$ & $(0.0018)$ \\
IPO year +3 & -0.0018 & $-0.0047^{* * *}$ & 0.0023 \\
& $(0.0013)$ & $(0.0018)$ & $(0.0023)$ \\
IPO year+ $>3$ & -0.0016 & -0.0021 & -0.0016 \\
& $(0.0011)$ & $(0.0017)$ & $(0.0019)$ \\
N obs & & & \\
$R^{2}$ & 11,880 & 11,073 & 807 \\
\hline p-value of F-test for & 0.54 & 0.61 & 0.58 \\
total effect equal to zero & & 0.008 & 0.783 \\
\hline
\end{tabular}

*** indicates the coefficient is significantly different from zero at the $1 \%$ level or less;

** indicates the coefficient is significantly different from zero at the $5 \%$ level;

* indicates that the coefficient is significantly different from zero at the $10 \%$ level 
Table 7:

\section{Changes in the Ownership Structure}

This table reports the changes in the ownership structure at the time of the IPO and in the three subsequent years. The time of the IPO is defined as the end of the year in which the company became listed on the Milan Stock Exchange. The control-group stake includes the stake of the largest shareholder in the company, all the stakes owned by members of his/her family, the stake of any other holder who signed a binding voting trust with him/her, as long as this trust is mentioned in the prospectus. The change of the control group's stake at the IPO is the fraction of total market value of equity sold by the control group at that time. The change of the control group's stake in the following three years is the fraction of total market value of equity (as measured at the IPO) sold by the controlling group, where all sales and purchases are computed at the IPO price (i.e., this figure is meant to capture the effective fraction divested, independent of the price at which it is divested). The turnover in control is defined as the change in the identity of the major shareholder and not simply a change in the CEO. Panel A reports the data for the entire sample. All the figures refer to 68 observations, except for column I and row III where there are only 61 observations. Panel B reports the data for the IPO of independent companies. All the figures refer to 38 observations, except for column I, where there are only 34 observations. Panel $\mathrm{C}$ reports the data for carve-outs. There are 30 observations, except for column I (27 observations) and row III (29 observations). The numbers reported are respectively the median, the mean and the standard deviation (in brackets).

\section{A: Whole sample}

\begin{tabular}{lccc}
\hline \hline Variable & Before IPO & At IPO & IPO +3 \\
& & & \\
Holdings of the & 98.4 & 70.0 & 62.7 \\
control group (\%) & 87.6 & $66.6^{1}$ & $61.4^{2}$ \\
& $(16.7)$ & $(12.3)$ & $(15.3)$ \\
& & & \\
Change in the holdings & & -5.2 & 0.0 \\
of the control group (\%) & & $-11.3^{* * *}$ & 3.7 \\
& & $(17.3)$ & $(33.0)$ \\
New equity issues & & & \\
\% market cap.at IPO & & $14.1^{* * *}$ & 0.0 \\
& & $(18.7)$ & $(21.8)$ \\
& & & \\
Number of & 3.0 & 3,325 & 1,900 \\
shareholders & 34.8 & $8,401^{1}$ & $4,906^{2}$ \\
& $(128.4)$ & $(12,650)$ & $(7,945)$ \\
& & & \\
Turnover in control (\%) & & & 13.6 \\
\hline \hline
\end{tabular}

*** Significantly different from zero at the $1 \%$ level.

${ }^{1}$ Significantly different from the value before the IPO at the $1 \%$ level.

${ }^{2}$ Significantly different from the value at the IPO at the $1 \%$ level. 


\section{B: Independent-company IPOs}

\begin{tabular}{lccc}
\hline \hline Variable & Before IPO & At IPO & IPO +3 \\
& & & \\
Holdings of the & 89.5 & 70.25 & 60.4 \\
control group (\%) & 83.6 & $66.6^{1}$ & $60.3^{2}$ \\
& $(18.3)$ & $(13.8)$ & $(17.0)$ \\
& & & \\
Change in the holdings & & 0.0 & -0.2 \\
of the control group (\%) & & $-6.1^{* * *}$ & -2.7 \\
& & $(8.8)$ & $(20.4)$ \\
New equity issues & & 15.5 & 0.0 \\
\% market cap.at IPO & & $14.3^{* * *}$ & $6.1^{* *}$ \\
& & $(13.2)$ & $(11.15)$ \\
Number of & & & \\
shareholders & 4.5 & 2,750 & 1,800 \\
& 44.9 & $7,884^{1}$ & $3,907^{2}$ \\
Turnover in control (\%) & & $(13,979)$ & $(8,132)$ \\
\hline \hline
\end{tabular}

\section{C: Carve-outs}

\begin{tabular}{lccc}
\hline \hline Variable & Before IPO & At IPO & IPO +3 \\
& & & \\
Holdings of the & 100.0 & 69.5 & 66.8 \\
control group (\%) & 92.7 & $66.3^{1}$ & 62.9 \\
& $(13.3)$ & $(10.3)$ & $(13.0)$ \\
& & -12.7 & 0.0 \\
Change in the holdings & & $-17.9^{* * *}$ & 12.0 \\
of the control group (\%) & & $(22.6)$ & $(43.4)$ \\
& & & \\
New equity issues & & 0.0 & 0.0 \\
\% market cap.at IPO & & $13.9^{* * *}$ & $11.4^{* * * *}$ \\
& & $(24.1)$ & $(30.6)$ \\
Number of & & & \\
shareholders & 2.0 & 4,600 & 2,040 \\
& 22.1 & $9,057^{1}$ & $6,110^{2}$ \\
& $(68.6)$ & $(10,935)$ & $(7,665)$ \\
Turnover in control (\%) & & & 17.9 \\
\hline \hline
\end{tabular}

*** Significantly different from zero at the $1 \%$ level.

** Significantly different from zero at the $5 \%$ level.

${ }^{1}$ Significantly different from the value before the IPO at the $1 \%$ level.

${ }^{2}$ Significantly different from the value at the IPO at the $5 \%$ level. 


\section{Table 8:}

\section{Post-IPO Decline in Profitability and Divestment by the Controlling Shareholder}

This table reports the OLS estimates of the effect of divestiture and pre-IPO increase of profitability on the post-IPO change in profitability. The time of the IPO is defined as the year in which the company became listed on the Milan Stock Exchange. The post-IPO change in profitability is measure as the four year change in ROA (EBITDA over total assets) after the IPO. The pre-IPO change in profitability is the change in ROA in the four year leading to the IPO. The change of the control group's stake at the IPO is the fraction of total market value of equity sold by the control group at that time. Standard errors are reported in brackets.

\begin{tabular}{lccc}
\hline \hline Variable & Whole Sample & Independent IPOs & Carve-outs \\
Pre-IPO change & -0.056 & -0.028 & $-0.178^{*}$ \\
in profitability & $(0.155)$ & $(0.284)$ & $(0.087)$ \\
Change in control- & -0.054 & 0.227 & $-0.122^{* * *}$ \\
group holdings & $(0.068)$ & $(0.305)$ & $(0.030)$ \\
& & & \\
N. Obs. & 36 & 19 & 17 \\
$R^{2}$ & 0.02 & 0.03 & 0.60 \\
\hline \hline
\end{tabular}

*** Significantly different from zero at the $1 \%$ level.

** Significantly different from zero at the $5 \%$ level.

* Significantly different from zero at the $10 \%$ level. 


\section{References}

[1] Barca, Fabrizio, Magda Bianco, Luigi Cannari, Riccardo Cesari, Carlo Gola, Giuseppe Manitta, Giorgio Salvo, and Luigi Signorini (1994), Proprietà, modelli di controllo e riallocazione nelle imprese industriali italiane, Il Mulino: Bologna.

[2] Basile, Ignazio (1988), "Gli intermediari creditizi e la quotazione di Borsa," in $L$ 'ammissione alla quotazione di Borsa: un'analisi interdisciplinare, M. Cattaneo et al. eds., Vita e Pensiero: Milano.

[3] Bebchuk, L. and Zingales, L. (1995), "Corporate Ownership Structures: Private versus Social Optimality," mimeo, University of Chicago, http://gsblgz.uchicago.edu.

[4] Bhattacharya, Sudipto, and Gabriella Chiesa (1994), "Proprietary Information, Financial Intermediation and Research Incentives," Discussion paper no. 186 (LSE Financial Markets Group).

[5] Bolton, Patrick, and Ernst-Ludwig von Thadden (1994), "The Ownership Structure of Firms: the Liquidity/Control Trade-off," mimeo ECARE and Universität Basel.

[6] Brealey, Richard and Stewart Myers (1991), Principles of Corporate Finance, McGraw-Hill: New York.

[7] Campbell, Tim (1979), "Optimal Investment Financing Decisions and the Value of Confidentiality," Journal of Financial and Quantitative Analysis 14, 913-24.

[8] Chemmanur, Thomas, and Paolo Fulghieri (1994), "Information Production, Private Equity Financing, and the Going Public Decision," mimeo Columbia University.

[9] Centrale dei Bilanci (1992), Economia e finanza delle imprese italiane (1982-1990), Il Sole 24 Ore Libri: Milano.

[10] Degeorge, François, and Richard Zeckhauser (1993), "The Reverse LBO Decision and Firm Performance: Theory and Evidence," Journal of Finance 48, 1323-1348.

[11] De Long, John B., Andrei Shleifer, Lawrence H. Summers and Robert J. Waldmann (1990), “Noise Trader Risk in Financial Markets," Journal of Political Economy 98, 703-738.

[12] Diamond, Douglas (1991), "Monitoring and Reputation: The Choice between Bank Loans and Directly Placed Debt," Journal of Political Economy 99, 689-721.

[13] Faini, Riccardo, Giampaolo Galli, and Curzio Giannini (1993), 'Finance and Development: The Case of Southern Italy," in Finance and Development: Issues and Experience, Alberto Giovannini ed., Cambridge University Press: Cambridge.

[14] Ferrari, Giampaolo (1992), "Il giudizio sulla quotazione di un gruppo di 'matricole'," in Le imprese che possono accedere alla Borsa Valori in Italia, Mario Massari ed., Il Sole 24 Ore Libri: Milano.

[15] Franks, Julian, and Colin Mayer (1994), "The Ownership and Control of German Corporations," mimeo LBS. 
[16] Fulghieri, Paolo and Luigi Zingales, (1995), "Privatizzazioni e struttura del controllo societario: il ruolo della public company." in F. Galimberti, F. Giavazzi, A. Penati and G. Tabellini (eds.) Le nuove frontiere della politica economica, Il Sole-24 ore: Milano.

[17] Gualtieri, Paolo (1988), "Gli effetti della quotazione ufficiale di Borsa sulla gestione finanziaria aziendale, ${ }^{n}$ in L'ammissione alla quotazione di Borsa: un'analisi interdisciplinare, M. Cattaneo et al. eds., Vita e Pensiero: Milano.

[18] Gompers, Paul (1992), "Grandstanding in the Venture Capital Industry," mimeo University of Chicago.

[19] Jain, Bharat A., and Omesh Kini (1994), "The Post-Issue Operating Performance of IPO Firms," The Journal of Finance 49, 1699-1726.

[20] Jensen, Michael C., and William H. Meckling (1976), "Theory of the Firm: Managerial Behavior, Agency Costs, and Ownership Structure," Journal of Financial Economics 11, 5-50.

[21] Holmström, Bengt, and Jean Tirole (1993), "Market Liquidity and Performance Monitoring", Journal of Political Economy 101, 678-709.

[22] Kadlec, Gregory B., and John J. McConnell (1994), "The Effect of Market Segmentation and Illiquidity on Asset Prices," Journal of Finance 49, 611-636.

[23] Kaplan S. N. (1991) "The Staying Power of Leverage Buyouts," Journal of Financial Economics 29: 287-313.

[24] Leland, Hayne E., and David H. Pyle (1977), "Informational Asymmetries, Financial Structure, and Financial Intermediation," Journal of Finance 32, 371-387.

[25] Ljungqvist, Alexander P. (1995), "When Firms Go Public? Poisson Evidence from Germany," mimeo, University of Oxford.

[26] Lerner, Joshua (1994), "Venture Capitalists and the Decision to Go Public," Journal of Financial Economics 35, 293-316.

[27] Loughran, Tim, Jay R. Ritter and Kristian Rydqvist (1994), "Initial Public Offerings: International Insights," Pacific-Basin Finance Journal 2, 165-199.

[28] Loughran, Tim and Jay R. Ritter, "The New Issues Puzzle," Journal of Finance 50, 23-51.

[29] Mayer, Colin, and Ian Alexander (1991), "Stock Markets and Corporate Performance: A Comparison of Quoted and Unquoted Companies," CEPR Discussion Paper No. 571.

[30] Massari, Mario (1992), Le imprese che possono accedere alla Borsa Valori in Italia, Il Sole 24 Ore Libri: Milano.

[31] Merton, Robert C. (1987), "Presidential Address: A Simple Model of Capital Market Equilibrium," Journal of Finance 42, 483-510.

[32] Michaely, Roni, and Wayne H. Shaw (1995), "The Choice of Going Public: Spin-offs vs. Carveouts," mimeo, Cornell University. 
[33] Mikkelson, Wayne H., Megan Partch and Ken Shah (1995), "Performance of Companies around Initial Public Offerings," mimeo, University of Oregon.

[34] Pagano, Marco (1993), "The Flotation of Companies on the Stock Market: A Coordination Failure Model," European Economic Review 37, 1101-1125.

[35] Pagano, Marco, and Ailsa Röell (1995), "The Choice of Stock Ownership Structure: Agency Costs, Monitoring and Liquidity," mimeo, Università Bocconi and ECARE.

[36] Panetta, Fabio, and Roberto Violi (1995), "Risk Premium, consumption, and Financial Structure from the Unification of Italy to Today," mimeo, Banca D'Italia.

[37] Planell, Sergio Bermejo (1995), "Determinantes y efectos de la salida a Bolsa en Espana: un analisis empirico," mimeo, Centro de Estudios Monetarios y Financieros.

[38] Rajan, Raghuram G. (1992), "Insiders and Outsiders: The Choice between Informed and Arm'sLength Debt," Journal of Finance 47, 1367-1400.

[39] Rajan, Raghuram G. and Henri Servaes (1995), "The Effect of Market Conditions on Initial Public Offerings," mimeo University of Chicago.

[40] Rajan, Raghuram G. and Luigi Zingales (1995), "What Do We Know About Capital Structure: Some Evidence From International Data," Journal of Finance December.

[41] Ritter, Jay R. (1984), "The Hot Issue Market of 1980," Journal of Business 32, 215-240.

[42] Ritter, Jay R. (1987), "The Costs of Going Public," Journal of Financial Economics 19, 269-281.

[43] Ritter, Jay R. (1991), "The Long-Run Performance of Initial Public Offerings," Joumal of Finance 46, 3-27.

[44] Rock, Kevin (1986) "Why New Issues Are Underpriced," Journal of Financial Economics 15, 187-212.

[45] Rondi, Laura, Alessandro Sembenelli and Giovanni Zanetti (1994), "Is Excess Sensitivity of Investment to Financial Factors Constant across Firms? Evidence from Panel Data on Italian Companies," Journal of Empirical Finance 1, 365-383.

[46] Rydqvist, Kristian, and Kenneth Högholm (1994), "Going Public in the 1980s: Evidence from Sweden," unpublished manuscript (Carnegie Mellon University).

[47] Shleifer, Andrei, and Robert W. Vishny (1986), "Large Shareholders and Corporate Control," Journal of Political Economy 94, 461-88.

[48] Yosha, Oved (1995), Information Disclosure Costs and the Choice of Financing Source," Journal of Financial Intermediation 4, 3-20.

[49] Zingales, Luigi (1994), "The Value of the Voting Right: A Study of the Milan Stock Exchange," The Review of Financial Studies 7, 125-148. 
[50] Zingales, Luigi (1995a), "Insiders' Ownership and the Decision to Go Public," The Review of Economic Studies 62: 425-448.

[51] Zingales, Luigi (1995b), "What Determines the Value of Corporate Votes?" Quarterly Journal of Economics November. 